\title{
New $\mathrm{Pt} \rightarrow \mathrm{M}(\mathrm{M}=\mathrm{Ag}, \mathrm{Tl})$ complexes based on anionic cyclometalated Pt(II) complexes
}

\begin{abstract}
David Campillo, Úrsula Belío, and Antonio Martín*
Anionic cyclometalated complexes $\left(\mathrm{NBu}_{4}\right)[\mathrm{Pt}(\mathrm{CNC}) \mathrm{X}](\mathrm{X}=\mathrm{Cl}(\mathbf{1}), \mathrm{CN}(\mathbf{2})$, S-2py (pyridine-2-thiolate) (3); -CNC- = 2,6-di(phen2-ide)-pyridine) have been used as precursors in the synthesis of heteropolynuclear Pt-Ag or Pt-Tl complexes containing donor-acceptor metal-metal bonds. Their reaction with $\mathrm{AgClO}_{4}$ or $\left[\mathrm{Ag}\left(\mathrm{OClO}_{3}\right)\left(\mathrm{PPh}_{3}\right)\right]$ produces complexes in which the nuclearity and structure seems to be determined by the ability of the ligand $X$ to form bridges between the metals. Thus, the characteristic linear bridging of the cyano ligand leads to the formation of an octanuclear $\left[\{\mathrm{Pt}(\mathrm{CNC})(\mu-\mathrm{CN})\}_{4} \mathrm{Ag}_{4}\right](4)$ or tetranuclear $\left[\{\mathrm{Pt}(\mathrm{CNC})(\mu-\mathrm{CN})\}_{2}\left\{\mathrm{Ag}\left(\mathrm{PPh}_{3}\right)\right\}_{2}\right](6)$ complexes, with $\mathrm{CN}$ bridges between different "Pt-Ag" units. However, the $\mathrm{S}-2$ py ligand can act as a bridge between $\mathrm{Pt}$ and $\mathrm{Ag}$ of the same "Pt-Ag" unit, giving rise to complex [ $\mathrm{Pt}(\mathrm{CNC})(\mathrm{S}-$ $\left.2 \mathrm{py})\}_{2} \mathrm{Ag}_{2}\right] \cdot \mathrm{CH}_{2} \mathrm{Cl}_{2}$ (5). On the other hand, the reaction of 1-3 with $\mathrm{TIPF}_{6}$ yields the complexes [PtTI(CNC)Cl] (7), [PtTI(CNC)(CN)] (8), $\left(\mathrm{NBu}_{4}\right)\left[\{\mathrm{Pt}(\mathrm{CNC})(\mathrm{S}-2 \mathrm{py})\}_{2} \mathrm{Tl}\right]$ (9), while with [TI(S-2py)] [PtTI(CNC)(S-2py)] (10) is obtained. The structures of all these $\mathrm{Pt}-\mathrm{Tl}$ complexes show a great variation, with several geometric arrangements which sometimes co-

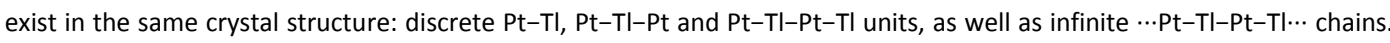
This variability could be due to a lability of the Pt-TI bonds and the ability of the thallium center to establish secondary interactions with donor atoms or aromatic $\pi$ electron density from neighboring moieties.
\end{abstract}

\section{Introduction}

Interactions between closed $\left(d^{10}, d^{10} s^{2}\right)$ or pseudo-closed $\left(d^{8}\right)$ shell metallic ions are a powerful tool in molecular and crystal engineering. $^{1-5}$ They have promoted the preparation of polynuclear metallic complexes that show very interesting structural features. Also, many of these complexes bear noteworthy photophysical properties, mostly related with their luminescent character. ${ }^{6-8}$ Moreover, their interest is growing lately as their presence is being recognised in polymetallic systems that play a crucial role in catalytic processes, such as $\mathrm{C}-\mathrm{C}$ or $\mathrm{C}-\mathrm{X}$ coupling reactions. ${ }^{9}$ In some of these processes, the formation of intermediate species with $M-M$ ' bonds which favour the interchange of the ligands bonded to the metal centres seems to be the key step of the catalytic cycle. ${ }^{10-20}$

Many of these metallophilic interactions can be described as dative bonds in which an electron density rich basic metal centre donates its electron density to an acidic metal species with empty orbitals able to host it. $\mathrm{Pt}(\mathrm{II})\left(\mathrm{d}^{8}\right)$ in a square planar environment is the most frequent donor centre. Formally, it owns an electron pair located in its $d_{z}^{2}$ orbital, perpendicular to the complex main square plane, which can be donated to a suitable acidic centre. Among these latter, the most commonly reported is $\mathrm{Ag}(\mathrm{I})^{21-24}$ and to a lesser extent $\mathrm{Au}(\mathrm{I}),{ }^{20,24} \mathrm{Cu}(\mathrm{I}),{ }^{10,18 \text {, }}$ ${ }^{25} \mathrm{TI}(\mathrm{I}),{ }^{26-29} \mathrm{Cd}(\mathrm{II}),{ }^{30,31} \mathrm{Hg}(\mathrm{II}),{ }^{32} \mathrm{~Pb}(\mathrm{II})^{27}$ and $\mathrm{Zn}(\mathrm{II}) .{ }^{19,} 33$

It has been found that the use of cyclometalated ligands in the $\mathrm{Pt}$ coordination sphere favors the formation of $\mathrm{Pt} \rightarrow \mathrm{M}$ dative bonds. ${ }^{6,20-23,32}$ Usually these ligands produce a lower steric hindrance that allows a better closeness of both metallic centres. Besides, the strong ligand field exerted by these cyclometalated ligands causes an increase in the energy of the Pt $\mathrm{d}_{\mathrm{z}}{ }^{2}$ orbital and promotes a stronger dative bond.

In the course of our previous work, we have reported the use of neutral $\mathrm{Pt}(\mathrm{II})$ complexes $[\mathrm{Pt}(\mathrm{CNC})(\mathrm{L})](\mathrm{CNC}=-\mathrm{CNC}-=2,6-$ di(phen-2-ide)-pyridine; $\left.\mathrm{L}=\mathrm{PPh}_{3}, \mathrm{SC}_{4} \mathrm{H}_{8}, \mathrm{CN}^{\mathrm{t}} \mathrm{Bu}\right)$ as starting materials in the synthesis of heteropolynuclear complexes containing $\mathrm{Pt} \rightarrow \mathrm{M}(\mathrm{M}=\mathrm{Ag}, \mathrm{Au}, \mathrm{TI})^{20,24,28,34}$ dative bonds. These neutral precursors have proved to be very adequate for this purpose and they allowed preparing polymetallic complexes that show very interesting molecular architectures. Thus, the use of $\mathrm{TI}(\mathrm{I})$ as the acidic metal led to the preparation of cyclic hexanuclear $\left[\mathrm{PtTI}(\mathrm{CNC})\left(\mathrm{CN}^{\mathrm{t}} \mathrm{Bu}\right)\right]_{3}{ }^{3+}$ or tetranuclear $\left[\{\mathrm{Pt}(\mathrm{CNC})\}_{3} \mathrm{TI}\right]^{+} \quad$ complexes, $^{28}$ while dinuclear $\left[(\mathrm{CNC})\left(\mathrm{PPh}_{3}\right) \mathrm{PtM}\left(\mathrm{PPh}_{3}\right)\right]$ or "sandwich" trinuclear $\left[\left\{(\mathrm{CNC})\left(\mathrm{PPh}_{3}\right) \mathrm{Pt}\right\}_{2} \mathrm{M}\right]$ complexes are obtained with $\mathrm{Au}(\mathrm{I})$ or $\mathrm{Ag}(\mathrm{I}) .{ }^{20}, 24$ Besides, these latter complexes have the added interest that they show $\mathrm{M}-\mathrm{C}$ interactions involving the $\mathrm{CNC}$ ligand which can be related with the potential participation of complexes with $\mathrm{M}-\mathrm{M}^{\prime}$ interactions in transmetalation processes.

In this paper we continue this study with the use of anionic $[\mathrm{Pt}(\mathrm{CNC}) \mathrm{X}]^{-}(\mathrm{X}=\mathrm{Cl}, \mathrm{CN}, \mathrm{S}-2 \mathrm{py}$ (pyridine-2-thiolate)) and their reactions toward $\mathrm{Ag}(\mathrm{I})$ or $\mathrm{TI}(\mathrm{I})$ salts and complexes. It has been pointed out that anionic square planar $\mathrm{Pt}(\mathrm{II})$ complexes should be better precursors than their neutral analogues because the metal centre should have more electron density to be donated to the acidic metal acceptor. The X-ray structural determinations of the resulting complexes have shown some remarkable features. 


\section{Results}

Preparation of the starting materials $\left(\mathrm{NBu}_{4}\right)[\mathrm{Pt}(\mathrm{CNC}) \mathrm{X}](\mathrm{X}=\mathrm{Cl}(1)$, CN (2), S-2py (3)).

The preparation of the starting materials $\left(\mathrm{NBu}_{4}\right)[\mathrm{Pt}(\mathrm{CNC}) \mathrm{X}]$ used in the syntheses of the Pt-M complexes was achieved by reactions of $[\mathrm{Pt}(\mathrm{CNC})(\mathrm{dmso})]$ with the corresponding $\mathrm{NBu}_{4} \mathrm{X}$. For $\mathrm{X}=\mathrm{Cl}$ a new experimental method was developed (see experimental), while for $\mathrm{X}=\mathrm{CN}$ and $\mathrm{S}-2 \mathrm{py}$, literature methods, with some minor variations, were used. ${ }^{35}$

The complexes 1-3 were identified and characterized by IR and ${ }^{1} \mathrm{H}$ NMR spectra. For $\mathbf{1}$, its crystal structure was determined by $\mathrm{X}$-ray diffraction. A view of the anion of complex $\mathbf{1}$ and a table with selected bond distances and angles appear in the Supporting Information (Figure S1 and Table S1). As expected, 1 shows a square planar environment for the Pt centre, with the CNC ligand also planar, and practically co-planar with the Pt square plane, and it is practically isostructural to the isoelectronic complex $[\mathrm{Au}(\mathrm{CNC}) \mathrm{Cl}]^{+36}$ Unlike to other similar $\mathrm{Pd}(\mathrm{II}), \mathrm{Pt}(\mathrm{II})$ or $\mathrm{Au}(\mathrm{III})$ square planar complexes, ${ }^{36-38}$ no intermolecular $\mathrm{M}-\mathrm{M}$ or $\pi \cdots \pi$ contacts are found in $\mathbf{1}$.

\section{Reactions of $\left(\mathrm{NBu}_{4}\right)[\mathrm{Pt}(\mathrm{CNC}) \mathrm{X}](\mathrm{X}=\mathrm{Cl}(1), \mathrm{CN}(2)$, S-2py (3)) with $\mathrm{AgClO}_{4}$.}

The reactions of the starting materials 1 and $\mathbf{2}$ with $\mathrm{AgClO}_{4}$ in 1:1 molar ratio using $\mathrm{CH}_{2} \mathrm{Cl}_{2}$ (1) or acetone (2) as solvent, and in the absence of light, lead to the progressive precipitation of solids which were filtered off after $60 \mathrm{~min}$ of stirring. In the case of the S-2py (3) only a faint precipitate appears and in order to obtain a good yield the solution is evaporated to dryness after $30 \mathrm{~min}$ of stirring. The resulting solid is treated with ${ }^{\mathrm{i}} \mathrm{PrOH}$ and the insoluble fraction is filtered off.

The scarce or zero solubility of these solids in acetone and in low or non-coordinating solvents such as $\mathrm{CH}_{2} \mathrm{Cl}_{2}$ or $\mathrm{CHCl}_{3}$ limits their study by NMR or mass spectroscopy. Thus, deuterated dimethyl sulphoxide $\left(d m s o-d^{6}\right)$ has to be used as the NMR solvent, but given its strong coordinative nature any possible Pt-M bond gets broken in solution and no further information can be obtained. In the case of the product obtained from 2, it is not even soluble enough in dmso- $d^{6}$ to record any NMR spectrum. At this point, the only information available for this solid came from their elemental analyses (see Experimental section) and its IR spectrum. The former agrees with the intended stoichiometry $[\mathrm{PtAg}(\mathrm{CNC})(\mathrm{CN})]$ while a remarkable feature for the latter is the displacement of the IR $v(C \equiv N)$ band toward higher frequencies $\left(2122 \mathrm{~cm}^{-1}\right)$ with respect to its starting material $2\left(2092 \mathrm{~cm}^{-1}\right)$, a shift observed in bridged cyano complexes.

Nevertheless, suitable crystals for X-ray diffraction studies were obtained from slow diffusion of concentrated dimethyformamide (DMF) solutions of this solid into diethyl ether. The crystal structure reveals the existence of an octanuclear cluster $\left[\{\mathrm{Pt}(\mathrm{CNC})(\mu-\mathrm{CN})\}_{4} \mathrm{Ag}_{4}\right]$ (4) (see Figure 1 and Table S2, Supporting Information).

One of the four "Pt(CNC)CN" fragments is disordered over two positions, each of the components giving rise to slightly different structural parameters with respect to the other fragments. Here, only one of the components of the disorder is used for descriptive purposes. A full insight of the complex can be obtained from the cif file available as Supporting Information.

The structure can be regarded as two " $\mathrm{Pt}(\mathrm{CNC})(\mathrm{CN})$ " fragments which sandwich two $\mathrm{Ag}$ centres. These " $\mathrm{Pt}_{2} \mathrm{Ag}_{2}$ " units in turn are joined through the cyano ligands which bridge platinum and silver atoms of analogous units. In each " $\mathrm{Pt}_{2} \mathrm{Ag}_{2}$ " unit the "Pt(CNC)(CN)" fragments are basically co-planar (dihedral angles: $4.5(2)^{\circ}(\mathrm{Pt}(1 \mathrm{~A})-\mathrm{Pt}(1 \mathrm{~B}))$ y $17.9(3)^{\circ}(\mathrm{Pt}(1 \mathrm{C})-\mathrm{Pt}(1 \mathrm{D}))$. The two " $\mathrm{Pt}_{2} \mathrm{Ag}_{2}$ " units are almost perpendicular one with respect to the other. Approximately, the core of complex $\mathbf{4}$ has a very distorted parallelepiped geometry in which the metallic centres occupy alternate vertex and the cyano ligands lie in the long edges (see Figure 1b).

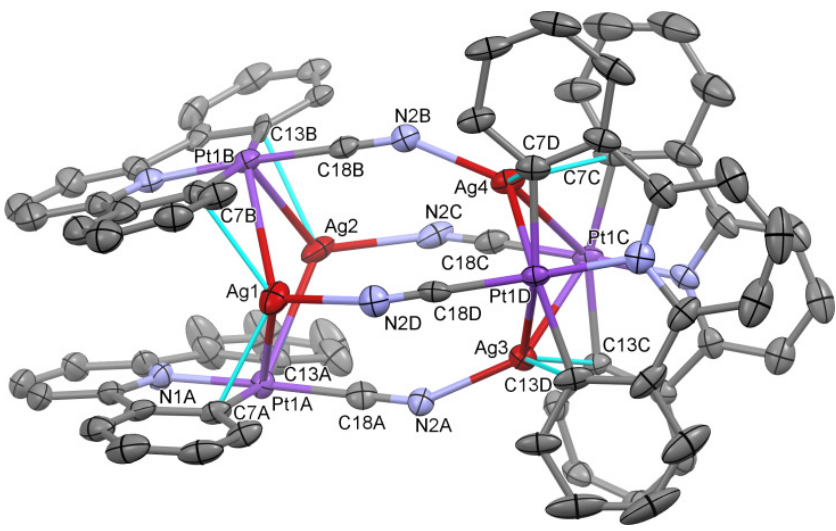

a)

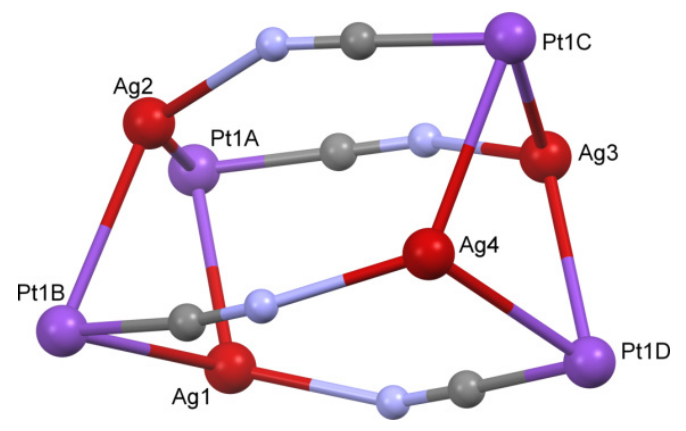

b)

Fig. 1. a) X-ray crystal structure of the complex $\left[\{\mathrm{Pt}(\mathrm{CNC})(\mu-\mathrm{CN})\}_{4} \mathrm{Ag}_{4}\right]$ (4). b) View of the core of the complex. For the sake of clarity, only one of the components of the disorder is represented. 


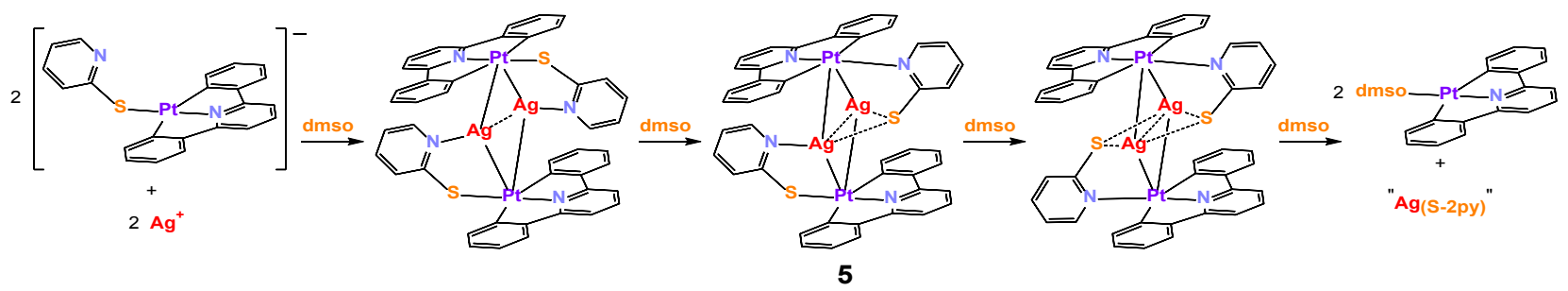

Scheme 1. Proposed path for the formation of $\mathbf{5}$ and its evolution.

Each silver atom is bonded to two platinum centres with distances between 2.7740(11) and 3.0408(5) Å (see Table S2), in the range found for this kind of dative bonds. ${ }^{21-24}$ The Pt-Ag lines always lean toward the ipso carbon of the phenylene rings of the $\mathrm{CNC}$ ligands. As a consequence, the $\mathrm{Ag}-\mathrm{C}_{\text {ipso }}$ distances are short, ranging from 2.466(14) and 2.577(5) $\AA$ (see Table S2), and indicating the existence of $\eta^{1}-\mathrm{Ag}-\mathrm{C}$ interactions. These interactions have been observed previously in other CNC complexes, ${ }^{20,24,39}$ or similar complexes containing other $\mathrm{CN}$ plane cyclometalated ligands such as benzoquinolate. ${ }^{21,22}$ DFT calculations performed on these systems have showed that in these $\mathrm{M} \cdots(\mathrm{Pt}-\mathrm{C})$ interactions there is a substantial participation of the electron density contained along the $\mathrm{Pt}-\mathrm{C}$ bond. $^{24}$

The structure confirms the bridging role of the cyano ligands which connect $\mathrm{Pt}$ and $\mathrm{Ag}$ centres from different " $\mathrm{Pt}_{2} \mathrm{Ag}_{2}$ " units. The Pt-C-N-Ag sequence is relatively linear, with the larger deviation corresponding to the $\mathrm{Ag}-\mathrm{N}-\mathrm{C}$ angle, around $150^{\circ}$ (see Table S2), as previously described in other "Pt-CN-Ag" or "Pt-CN-Cu" complexes. ${ }^{40}$

Finally, the $\left[\{\mathrm{Pt}(\mathrm{CNC})(\mu-\mathrm{CN})\}_{4} \mathrm{Ag}_{4}\right]$ moieties in the crystal structure establish $\pi \cdots \pi$ interactions with the aromatic rings of the CNC ligands of neighbour complexes (C...C less than $3.5 \AA$ ), thus forming a supramolecular chain (see Figure S8, Supporting Information). This arrangement has been previously observed in other $\mathrm{Pt}(\mathrm{CNC})$ complexes. ${ }^{28}$

In the case of the very insoluble material obtained from the reaction of $\left(\mathrm{NBu}_{4}\right)[\mathrm{Pt}(\mathrm{CNC})(\mathrm{S}-2 \mathrm{py})]$ (3) with $\mathrm{AgClO}_{4}$, their elemental analyses (see Experimental section) lead us to assign it a formula [PtAg(CNC)(S-2py)]. We also have detected a peak corresponding to the $\left[\left[\{\mathrm{Pt}(\mathrm{CNC})(\mathrm{S}-2 \mathrm{py})\}_{2} \mathrm{Ag}_{2}\right]+\mathrm{H}\right]^{+}$species in its mass spectrum (see Experimental section). Besides, and despite its low solubility, a small amount of this solid could be dissolved in $\mathrm{CH}_{2} \mathrm{Cl}_{2}$ and the slow diffusion of this solution into $n$-hexane gave some few crystals suitable for $\mathrm{X}$-ray diffraction studies. The crystal structure confirms again the 1:1 ratio between the metal centres, in this case being a tetranuclear complex of formula $\left[\{\mathrm{Pt}(\mathrm{CNC})(\mathrm{S}-2 \mathrm{py})\}_{2} \mathrm{Ag}_{2}\right](5)$ (see Figure 2 and Table S3, Supporting Information).

As in complex 4, we find a " $\mathrm{Pt}_{2} \mathrm{Ag}_{2}$ " unit in the structure of $\mathbf{5}$. Thus, the two silver centres are located between the two "Pt(CNC)" units but in this case these are not coplanar (dihedral angle of $38.5^{\circ}$ ). The S-2py ligands are bridging the $\mathrm{Pt}$ and $\mathrm{Ag}$ atoms, but it is noteworthy that one of the mercaptopyridines has changed its coordination mode and is now $\mathrm{N}$-bonded to $\mathrm{Pt}(1)$ and $\mathrm{S}$-bonded to the two silver centres. Although the S-coordination of the S-2py ligand to the $\mathrm{Pt}$ centre is more often observed, its $\mathrm{N}$-coordination has been reported once in the related compound $\left[\left\{\mathrm{Pt}\left(\mathrm{C}_{6} \mathrm{~F}_{5}\right)(\mathrm{S}\right.\right.$ - $\left.2 p y)(\mathrm{ppy})\}_{2} \mathrm{~Pb}\right]{ }^{32}$ which is prepared by reaction of $\left.\left[\mathrm{Pt}\left(\mathrm{C}_{6} \mathrm{~F}_{5}\right)(\mathrm{ppy})(\mathrm{dmso})\right\}\right]$ with $\left[\mathrm{Pb}(\mathrm{S}-2 \mathrm{py})_{2}\right]$. In any case, the structure of 5 reveals that the breakage of a $\mathrm{Pt}-\mathrm{S}$ bond and concomitant formation of a Pt-N takes place. It is worth noting that when the crude solid from which crystals of $\mathbf{5}$ is obtained by recrystallization is dissolved in dmso- $d^{6}$ with the aim to measure its ${ }^{1} \mathrm{H}$ NMR spectrum, signals corresponding to the complex $[\mathrm{Pt}(\mathrm{CNC})(\mathrm{dmso})]$ are observed, ${ }^{28}$ along three more signals which are attributed to some "Ag(S-2py)" complexes. ${ }^{41}$ Since S-2py is able to bridge $\mathrm{Pt}$ and $\mathrm{Ag}$ centres of the same " $\mathrm{Pt}_{2} \mathrm{Ag}_{2}$ " unit, complex 5 could evolve through a path as the one represented in Scheme 1, finally giving [Pt(CNC)(dmso)] and "Ag(S-2py)" as observed in its ${ }^{1} \mathrm{H}$ NMR spectra in dmso. The crystal structure found in $\mathbf{5}$ would be a snapshot of this evolution.

The two silver centres show very different environments. Thus, $\mathrm{Ag}(1)$ is bonded to the two platinum atoms with $\mathrm{Pt}-\mathrm{Ag}$ distances at the longer end for donor acceptor systems (3.0380(7) and 3.0360(7) $\AA$ ) and no $\mathrm{Ag}(1)-C_{\text {ipso }}$ contacts are established (the Ag- $\mathrm{C}_{\text {ipso }}$ distances are above $3 \AA$ ). Besides, $\mathrm{Ag}(1)$ is bonded to a pyridinic nitrogen atom and the $S$ atom of the "inverted" S-2py ligand. This S atom bridges the two silver centres, but with different $\mathrm{Ag}-\mathrm{S}$ distances $(\mathrm{Ag}(1)-\mathrm{S}(1)=$ 2.422(2), $\mathrm{Ag}(2)-\mathrm{S}(1)=2.601(2) \AA)$. On the other hand, the $\mathrm{Pt}-\mathrm{Ag}(2)$ distances are shorter (2.8659(7) and 2.8237(7) $\AA$ ) and this silver centre contacts with two $C_{i p s o}$ atoms of the CNC ligands, with short $A g-C_{i p s o}$ distances $(A g(2)-C(7)=2.386(8) \AA$, $\mathrm{Ag}(2)-\mathrm{C}(29)=2.355(8) \AA \AA$ ). Concomitantly, the Pt-Ag lines lean toward the phenylene rings of the CNC ligands in a greater extent for $\mathrm{Ag}(2)$.

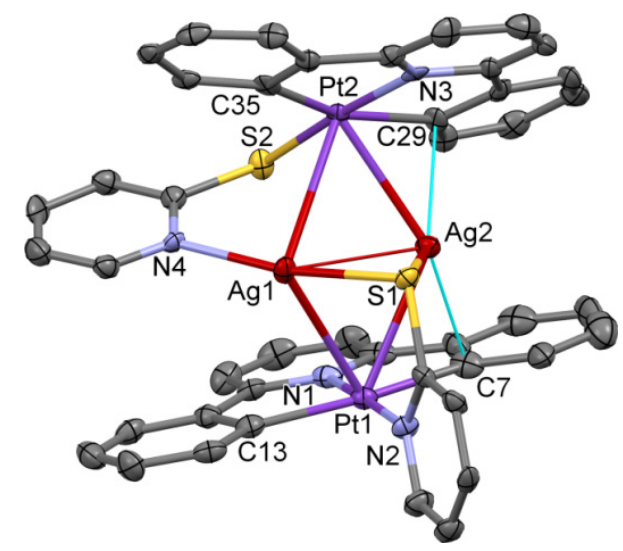

Fig. $2 \mathrm{X}$-ray crystal structure of the complex $\left[\{\mathrm{Pt}(\mathrm{CNC})(\mathrm{S}-2 \mathrm{py})\}_{2} \mathrm{Ag}_{2}\right](\mathbf{5})$ 


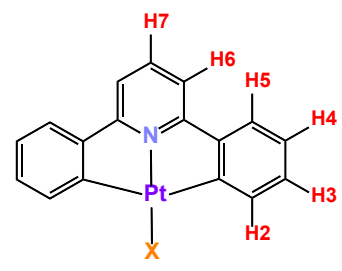

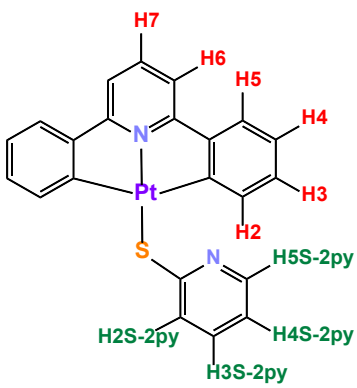

Chart 1. Atom numbering scheme used for the description of the NMR spectra.

The different bonding mode of the silver centres seems to indicate that given their acidic nature they seek electron density from the surroundings in a different way. The donation of the electron pair of the pyridinic nitrogen to $\operatorname{Ag}(1)$ and a closer $A g(1)-S(1)$ interaction seems to cause that this silver atom is not so avid for additional electron density, and thus the Pt-Ag(1) distances are longer and there is no need for additional $\mathrm{Ag}-\mathrm{C}_{\text {ipso }}$ contacts. However, $\mathrm{Ag}(2)$ finds this additional electron density in stronger $\mathrm{Pt}-\mathrm{Ag}$ interactions (leading to shorter $\mathrm{Pt}-\mathrm{Ag}$ distances) and $\mathrm{Ag}-\mathrm{C}_{\text {ipso }}$ contacts.

The $\operatorname{Ag}(1) \cdots A g(2)$ separation is $2.891(1) \AA$, significantly shorter than for 4 (around $3.4 \AA$ ) which could indicate that some argentophilic interaction may exist. ${ }^{42}$

\section{Reactions of $\left(\mathrm{NBu}_{4}\right)[\mathrm{Pt}(\mathrm{CNC}) \mathrm{X}](\mathrm{X}=\mathrm{Cl}(1), \mathrm{CN}(2), \mathrm{S}-2 \mathrm{py}(3))$ with $\left[\mathrm{Ag}\left(\mathrm{OClO}_{3}\right)\left(\mathrm{PPh}_{3}\right)\right]$.}

In order to prepare more Pt-Ag complexes, the reactions of the starting materials 1-3 with $\left[\mathrm{Ag}\left(\mathrm{OClO}_{3}\right)\left(\mathrm{PPh}_{3}\right)\right]$ in 1:1 molar ratio were explored. Nevertheless, only in the case of the starting material $\mathbf{2}$ were the results successful, while in the other two cases, an interchange of ligands between the metal centres is observed.

Thus, the reaction of $\left(\mathrm{NBu}_{4}\right)[\mathrm{Pt}(\mathrm{CNC}) \mathrm{Cl}]$ (1) with $\left[\mathrm{Ag}\left(\mathrm{OClO}_{3}\right)\left(\mathrm{PPh}_{3}\right)\right]$ in acetone causes, after some minutes of stirring, the precipitation of $\mathrm{AgCl}$. This solid is filtered off and after evaporation of the solvent, a yellow solid is obtained. This solid is identified (IR, NMR) as $\left[\mathrm{Pt}(\mathrm{CNC})\left(\mathrm{PPh}_{3}\right)\right]$, previously prepared. $^{20}$

In the case of $\left(\mathrm{NBu}_{4}\right)[\mathrm{Pt}(\mathrm{CNC})(\mathrm{S}-2 \mathrm{py})]$ (3), the reaction with $\left[\mathrm{Ag}\left(\mathrm{OClO}_{3}\right)\left(\mathrm{PPh}_{3}\right)\right]$ in similar conditions yields a yellow solid which spectroscopic data, mainly NMR, indicate that it is a mixture of, again, $\left[\mathrm{Pt}(\mathrm{CNC})\left(\mathrm{PPh}_{3}\right)\right]$ and a compound that causes the same mercaptopyridine signals than in the ${ }^{1} \mathrm{H}$ NMR spectrum of $\mathbf{5}$, described above, which were attributed to unidentified "Ag(S-2py)" complexes.

Furthermore, the reaction of $\left(\mathrm{NBu}_{4}\right)[\mathrm{Pt}(\mathrm{CNC})(\mathrm{CN})]$ (2) with $\left[\mathrm{Ag}\left(\mathrm{OClO}_{3}\right)\left(\mathrm{PPh}_{3}\right)\right]$ in acetone at room temperature during 30 minutes in the absence of light causes the precipitation of a yellow brownish solid, which is filtered off and air dried. The IR spectrum of this solid lacks the signals corresponding to the $\mathrm{NBu}_{4}{ }^{+}$or $\mathrm{ClO}_{4}{ }^{-}$ions, confirming its neutral nature. Moreover, the $\mathrm{v}(\mathrm{C} \equiv \mathrm{N})$ band moves toward higher frequencies $\left(2117 \mathrm{~cm}^{-1}\right)$ with respect to the starting material $\left(2092 \mathrm{~cm}^{-1}\right)$ which is consistent with a bridging role for the cyano ligand. ${ }^{43}$
Additionally, the elemental analysis for this solid is compatible with a formula [Pt(CNC)(CN)Ag( $\left.\left.\mathrm{PPh}_{3}\right)\right]$.

The ${ }^{1} \mathrm{H}$ NMR spectrum of this solid in $\mathrm{CD}_{2} \mathrm{Cl}_{2}$ (see Figure $\mathrm{S} 13$, Supporting Information) shows only four signals in the aromatic region which can be assigned to the $\mathrm{CNC}$ and $\mathrm{PPh}_{3}$ ligands (see experimental section for the assignment of the signals). The pattern of the signals corresponding to the CNC ligand is significantly different from the one found in the starting material 2. Particularly, the signal corresponding to $\mathrm{H} 2$ (see Chart 1a for the proton numbering Scheme) appears perceptibly deshielded $(8.23 \mathrm{ppm})$ with respect to the starting material $(7.88 \mathrm{ppm})$, which again is an indication of the existence of $\mathrm{Pt} \rightarrow \mathrm{M}$ bonds. ${ }^{20,28,39}$

The ${ }^{31} \mathrm{P}$ NMR spectrum in $\mathrm{CD}_{2} \mathrm{Cl}_{2}$ at room temperature only shows a broad signal. Successive spectra recorded while cooling down the sample show a progressive increasing of the resolution of this broad signal in such a way that at $193 \mathrm{~K}$ (see Figure 3 ) it appears as two doublets. This pattern is typical for the phosphorus atoms of a $\mathrm{PPh}_{3}$ ligand bonded to a silver centre, $^{22,44}$ and caused by the coupling ${ }^{44}$ of the ${ }^{31} \mathrm{P}$ nucleus to the two isotopomers ${ }^{107} \mathrm{Ag}$ (abundance $51.8 \%$ ) and ${ }^{109} \mathrm{Ag}$ (abundance $48.2 \%$ ) which have slightly different gyromagnetic constants, the Ag-P coupling constants being $638.7 \mathrm{~Hz}$ and $552.0 \mathrm{~Hz}$. In addition, a remarkable feature of these doublets is that they show platinum satellites $\left({ }^{2} J_{\mathrm{P}-\mathrm{Pt}}=100.5 \mathrm{~Hz}\right)$ that prove the existence of a Pt-Ag bond in solution.

The ${ }^{195} \mathrm{Pt}\left\{{ }^{1} \mathrm{H}\right\}$ NMR spectrum of the solid in $\mathrm{CD}_{2} \mathrm{Cl}_{2}$ is also consistent with the persistence of the $\mathrm{Pt}-\mathrm{Ag}$ bond in solution, Thus, the spectrum at room temperature shows a broad singlet which resolves in a doublet of doublets at 193K (see Figure S14, Supporting Information). This signal is centred at $4012 \mathrm{ppm}$, which represent a downfield shift of $21 \mathrm{ppm}$ with respect to the starting material 2 . Such displacement is in agreement with the existence of the intermetallic bond. The doublet of doublets is caused by a Pt-Ag coupling $\left({ }^{1} J_{\mathrm{Pt}-\mathrm{Ag}}=\right.$ $212.9 \mathrm{~Hz})$ and a further Pt-P coupling $\left({ }^{2} J_{\mathrm{Pt}-\mathrm{P}(\mathrm{Ag})}=108.6 \mathrm{~Hz}\right)$.

In the light of these results it is clear that the cyano starting material is able to stabilize a Pt-Ag complex in solution while the chloro or mercaptopyridine are not. Nevertheless, from the information given by the NMR it is not possible to determine the nuclearity of the complex in solution. The mass spectra (see Experimental) finds a peak corresponding to a dinuclear PtAg moiety, but equilibria in solution involving di and tetranuclear species may well be operating.

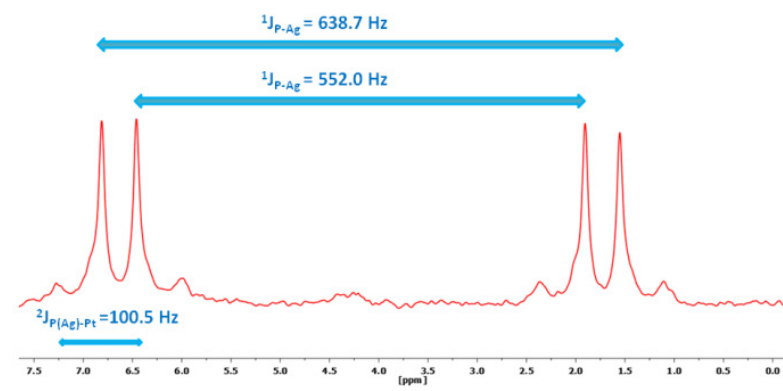

Figure 3. ${ }^{31} \mathrm{P}$ NMR spectrum $\left(\mathrm{CD}_{2} \mathrm{Cl}_{2}, 193 \mathrm{~K}\right)$ of 6 . 


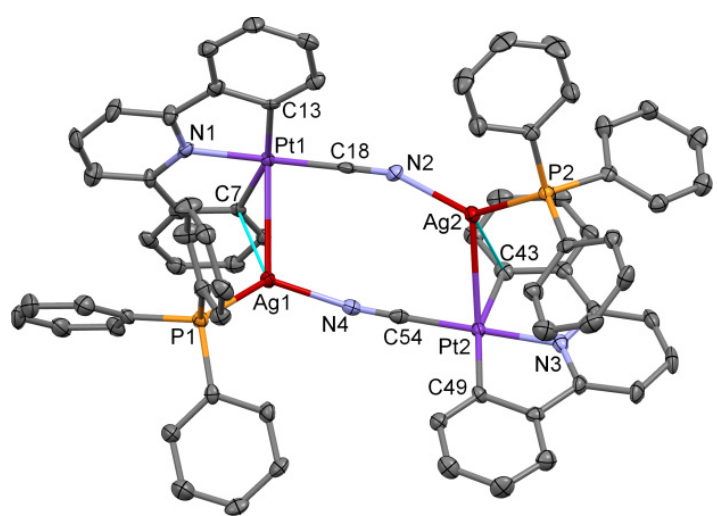

Figure 4. X-ray crystal structure of the complex $\left[\{\mathrm{Pt}(\mathrm{CNC})(\mu-\mathrm{CN})\}_{2}\left\{\mathrm{Ag}\left(\mathrm{PPh}_{3}\right)\right\}_{2}\right](6)$.

A single crystal X-ray diffraction study could stablish that on the solid we have a tetranuclear complex $[\{\mathrm{Pt}(\mathrm{CNC})(\mu-$ $\left.\mathrm{CN})\}_{2}\left\{\mathrm{Ag}\left(\mathrm{PPh}_{3}\right)\right\}_{2}\right]$ (6) (see Figure 4 and Table S4, Supporting Information).

As can be seen in Figure 4, 6 is formed by two "(CNC) $(\mathrm{CN}) \mathrm{PtAg}\left(\mathrm{PPh}_{3}\right)$ " subunits which are linked by the two cyano ligands that bridge the $\mathrm{Pt}$ and $\mathrm{Ag}$ atoms of different subunits. The structure of a similar complex, $[\{\mathrm{Pt}($ tolpy $)(\mathrm{CN})(\mu-$ $\mathrm{CN})\}_{2}\left\{\mathrm{Ag}\left(\mathrm{PPh}_{3}\right\}_{2}\right]$ (Htolpy $=2$-(4-tolyl)-pyridine), has recently been reported. ${ }^{40}$

In 6, the Pt-C-N-Ag sequence is fairly straight. The eightmember ring formed by the four metal atoms and the $\mathrm{C}$ and $\mathrm{N}$ of the cyano ligands does not depart dramatically from the planarity.

The best square plane environment of the platinum atoms are almost mutually perpendicular (dihedral angle $87.7(1)^{\circ}$ ). In each subunit there is a Pt-Ag bond with distances 2.9055(5) and 2.8652(5) $\AA$, similar to the ones found in 4 (see above), slightly shorter than the ones found in the analogous $\left[\{\mathrm{Pt}(\text { tolpy })(\mathrm{CN})(\mu-\mathrm{CN})\}_{2}\left\{\mathrm{Ag}\left(\mathrm{PPh}_{3}\right\}_{2}\right](2.9507(2) \AA),{ }^{40}\right.$ and in the range found for this kind of dative bonds. ${ }^{21-24}$ As in 4, the Pt-Ag line is not perpendicular to the Pt square plane, but leans toward one of the phenylene rings of the $\mathrm{CNC}$, resulting in short $\eta^{1}-A g-C$ interactions. The coordination of the silver centre in 6 is completed by a $\mathrm{PPh}_{3}$ ligand and a $\mathrm{Ag}-\mathrm{N}$ bond established with the nitrogen atom of the $\mathrm{CN}$ ligand of the other subunit. Disregarding the $\mathrm{Ag}-\mathrm{C}_{i p s o}$ interaction, the coordination spheres of the silver centres are approximately trigonal. In fact, the structure of 6 can be derived from the previously described for $\mathbf{4}$. The situation in the former is as in $\mathbf{4}$ each " $\mathrm{Pt}_{2} \mathrm{Ag}_{2}$ " subunit is split in two " $\mathrm{PtAg}$ " halves by the phosphane ligand.

It is worth mentioning that the $\mathrm{Ag}-\mathrm{C}_{\text {ipso }}$ interactions found in the crystal structures of $\mathbf{4 , 5}$ and $\mathbf{6}$ break the symmetry of the CNC ligand and thus, a static situation should cause an inequivalence of the signals of the CNC protons in the ${ }^{1} \mathrm{H} N M R$ spectra in solution. Unfortunately, only in the case of the $\mathbf{6}$, solubility does allow a complete NMR study. Both at room temperature and at $193 \mathrm{~K}$ the two halves of the CNC ligand are equivalent in the ${ }^{1} \mathrm{H}$ NMR spectra. Thus, either the $\mathrm{Ag}-\mathrm{C}_{\text {ipso }}$ interaction is not present is solution, or an oscillating dynamic process involving the alternate formation and breaking of the
$\mathrm{Ag}-\mathrm{C}_{\text {ipso }}$ interaction must be operating. This "metronome-like" process has been detected in the similar complexes $\left[(\mathrm{CNC})\left(\mathrm{PPh}_{3}\right) \mathrm{PtAu}\left(\mathrm{PPh}_{3}\right)\right]^{+}$and $\left[\left\{(\mathrm{CNC})\left(\mathrm{PPh}_{3}\right) \mathrm{Pt}_{2} \mathrm{Au}\right]^{+},{ }^{20,}{ }^{24}\right.$ for which the low temperature ${ }^{1} \mathrm{H}$ NMR spectrum shows the inequivalence of the two phenylene rings and thus a slowing of the oscillation. This difference in the energetic barrier of this process in these complexes with respect to $\mathbf{6}$ could be attributed to a stronger interaction in the gold complexes, where shorter $\mathrm{Au}-\mathrm{C}_{\text {ipso }}$ distances (2.157(3)-2.225(3) $\AA$ ) were found.

\section{Reactions of $\left(\mathrm{NBu}_{4}\right)[\mathrm{Pt}(\mathrm{CNC}) \mathrm{X}](\mathrm{X}=\mathrm{Cl}(1), \mathrm{CN}(2), \mathrm{S}-2$ py (3)) with $\mathrm{TIPF}_{6}$.}

Different results are obtained in the reactions in acetone of equimolecular amounts of $\mathrm{TIPF}_{6}$ with the starting materials $\left(\mathrm{NBu}_{4}\right)[\mathrm{Pt}(\mathrm{CNC}) \mathrm{X}]$ depending on $\mathrm{X}$. Thus, when $\mathrm{X}=\mathrm{Cl}$ or $\mathrm{CN}$, the precipitation of orange and yellow solids respectively is observed almost immediately. Identical solids (IR) are also obtained when the Pt/TI ratio is 2:1. On the other hand, the same reactions with $\left(\mathrm{NBu}_{4}\right)[\mathrm{Pt}(\mathrm{CNC})(\mathrm{S}-2 \mathrm{py})]$ as starting material do not produce the precipitation of a solid in the acetone solutions. After 35 minutes of stirring, the solution is evaporated to dryness, and the resulting solid treated with 'PrOH, from which an insoluble dark brown solid can be filtered off. This solid, as its IR and NMR data indicate (see below) is also obtained regardless of the $\mathrm{Pt} / \mathrm{TI}$ ratio used (1:1 or $2: 1$ ).

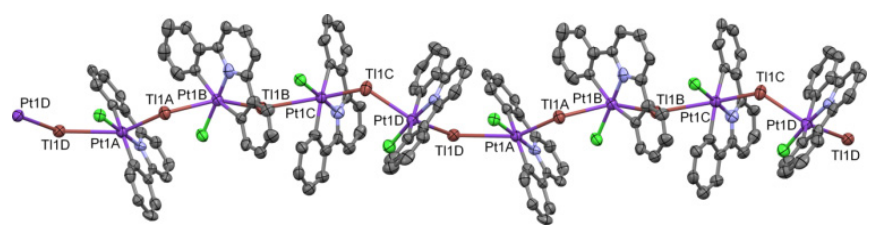

a)

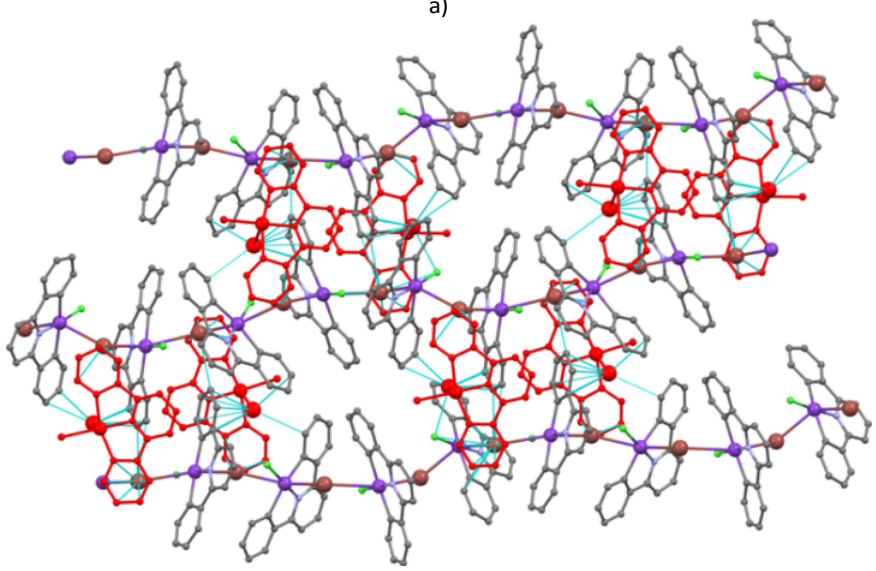

b)

Figure 5. a) Fragment of the infinite chain $[\mathrm{PtTI}(\mathrm{CNC}) \mathrm{Cl}]_{n}$ found in the $\mathrm{X}$-ray crystal structure of 7. b) Supramolecular two-dimensional structure. The E and $F$ $\eta$-arene-Tl interactions shorter than $3.4 \AA$ A.

Due to the very scarce solubility of the solids obtained from the $\mathrm{Cl}$ and $\mathrm{CN}$ starting materials in acetone or $\mathrm{CH}_{2} \mathrm{Cl}_{2}$, no NMR studies can be performed in these or other non-coordinative usual solvents. Only in dmso, a strong coordinative solvent, are these solids soluble enough to register their NMR spectra, and in these the absence of signals attributable to $\mathrm{NBu}_{4}{ }^{+}\left({ }^{1} \mathrm{H} \mathrm{NMR}\right)$ 
or $\mathrm{PF}_{6}{ }^{-}\left({ }^{19} \mathrm{~F} \mathrm{NMR}\right)$ is the most remarkable feature. The rest of signals in the proton spectrum correspond to the starting materials, and thus the existence of $\mathrm{Pt}-\mathrm{Tl}$ bonds in these solutions cannot be established. For the solid obtained from the chloro starting material, despite it being little soluble in acetone, some very few small crystals were obtained from slow diffusion of saturated $\mathrm{Me}_{2} \mathrm{CO}$ solutions of this solid into $n$ hexane. The quality of these crystals was far from ideal, being poor diffractors, but after some work in the resolution and refinement processes (see Experimental for crystallographic details) the crystal structure of $[\mathrm{PtTI}(\mathrm{CNC}) \mathrm{Cl}]$ (7) could be determined (see Figure 5 and Table S5, Supporting Information). Despite this structure is in agreement with a 1:1 $\mathrm{Pt}: \mathrm{Tl}$ ratio, as expected, we cannot assure that it is representative of the composition of the bulk solid obtained from the reaction, since no elemental analysis coincident with this formula could be obtained from repeated preparations of the solid.

The structure confirms the existence of Pt-TI bonds in the solid state. In the asymmetric part of the unit cell there are six "(CNC)CIPt-Tl" units which play different structural roles, giving rise to a two-dimensional framework. Four of these units (represented by the letters A-D) form a chain that, by repetition, becomes infinite (Figure 5a). The " $\mathrm{Pt}_{4} \mathrm{Tl}_{4}$ " asymmetric motif is 21.123(1) A long.

The atom sequence $\cdots \mathrm{Pt}-\mathrm{Tl}-\mathrm{Pt}-\mathrm{Tl}-\mathrm{Pt}-\mathrm{Tl} \cdots$ is not linear. The $\mathrm{Pt}-\mathrm{Tl}$ distances show a noticeable variability, with values between 2.8563(9) $\AA$ and 3.3644(9) $\AA$. The Pt-TI lines are not perpendicular to their $\mathrm{Pt}$ square planes, but the $\mathrm{Tl}$ atoms "lean" toward the chlorine atom of one of the neighbour "(CNC)ClPt" units, resulting relatively short $\mathrm{Tl}-\mathrm{Cl}$ distances, of around $3.12 \AA$, which could be indicative of some $\mathrm{Tl}-\mathrm{Cl}$ interaction. $\mathrm{TI}(1 \mathrm{C})$ is an exception to this feature since it is further than $3.5 \AA$ from its closest chloro ligands and at the same time shows two of the shortest Pt-Tl distances (2.8882(9) $\AA$, 2.9883(10) Å) and a less pronounced "leaning". The variability of all these geometric parameters found in the four "(CNC)ClPt-Tl" units that form the Pt-Tl chain could be due to packing forces and the flexibility of the

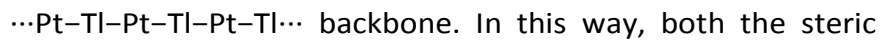
requirements of the crystal environment and the electronic requirements of the $\mathrm{TI}(\mathrm{I})$ acidic centre, which receives electron density from the $\mathrm{Pt}$ centres and the $\mathrm{Tl}-\mathrm{Cl}$ contacts can be fulfilled. It is worth mentioning that so far, only four other infinite one dimensional chains based solely in $\mathrm{Pt}-\mathrm{Tl}$ bonds (no bridging ligands) have been reported: $\left(\mathrm{NBu}_{4}\right)_{n}\left[\left\{\mathrm{Pt}\left(\mathrm{C}_{6} \mathrm{~F}_{5}\right)_{4}\right\} \mathrm{TI}\right]_{n}{ }^{45}$ $\left[\left\{\mathrm{Pt}(\mathrm{bzq})\left(\mathrm{C}_{6} \mathrm{~F}_{5}\right)_{2}\right\} \mathrm{TI}\left(\mathrm{Me}_{2} \mathrm{CO}\right)\right]_{n}{ }^{27}{ }^{27}\left(\mathrm{NBu}_{4}\right)_{n}[\{$ trans, trans, trans$\left.\left.\operatorname{PtTl}\left(\left[\operatorname{Pt}\left(\mathrm{C}_{6} \mathrm{~F}_{5}\right)\left(\mathrm{C}^{\wedge} \mathrm{N}\right)(\mathrm{S})\right]\right)_{2}(\mathrm{C} \equiv \mathrm{CFC})_{2}\right\}\right]_{\mathrm{n}}{ }^{46}$ and $\left[\left\{\mathrm{Pt}\left(\mathrm{C}_{6} \mathrm{~F}_{5}\right)(\mathrm{bzq})\right\} \mathrm{TI}(\mathrm{S}-\right.$ $\left.2 \mathrm{py}\left(\mathrm{F}_{3}\right)\right]_{\mathrm{n}}{ }^{26}$

The other two "(CNC)ClPt-Tl" units present in the asymmetric part of the unit cell (denoted E and F) are not part of the chain. Their structural role is to bridge adjacent parallel chains through interactions established by $\mathrm{Tl}$ atoms (see Figure 5b). These interactions are of two types. Firstly, the two phenylene rings of the CNC ligands of the $E$ and $F$ units establish $\eta$-arene$\mathrm{Tl}$ interactions with $\mathrm{Tl}$ centres of the neighbour chains, the shortest $\mathrm{Tl}-\mathrm{C}$ distances being around $3.2 \AA$. Besides, the $\mathrm{TI}$ atoms of the $E$ and $F$ units also show similar $\eta$-arene-Tl interactions with the CNC ligands of the chain. The final result is a two dimensional distribution of parallel ...Pt-TI-Pt-TI-Pt-TI... chains formed by the A-D units linked by the $n$-arene- $\mathrm{Tl}$ interactions of the $\mathrm{E}-\mathrm{F}$ units.

In the case of the solid obtained from the cyano starting material 2, their elemental analysis do correspond with the expected formulation [PtTI(CNC)(CN)] (8) (see Experimental). Moreover, we were able to obtain crystals from this solid suitable for X-ray studies which reveal a structure in accordance with this formula. The structural determination confirms the existence of Pt-Tl bonds in this complex (see Figure 6 and Table S6, Supporting Information). Besides, the $\mathrm{Pt}-\mathrm{Tl}$ units are connected through $\mathrm{Tl}-\mathrm{N}$ interactions.

In the asymmetric unit of $\mathbf{8}$ there are two virtually identical [PtTI(CNC)(CN)] moieties (see Figure 6a) with Pt-TI distances 2.9241(3) and 2.9207(3) $\AA$. These distances are in the short range found for this kind of intermetallic bond. For example, they are similar or slightly shorter to the ones reported in the "Pt(CNC)" complexes $\left[\{\mathrm{Pt}(\mathrm{CNC})(\mathrm{tht})\}_{3} \mathrm{TI}\right]^{+}(2.9088(5) \AA)$ and $\left[\left\{\mathrm{PtTI}(\mathrm{CNC})\left(\mathrm{CN}^{t} \mathrm{Bu}\right)\right\}_{3}\right]^{3+}(3.0143(3), 3.0488(3)$ and 3.0460(3) $\AA){ }^{28}$ and slightly shorter than the ones found in other "( $\left.\mathrm{C}^{\wedge} \mathrm{N}\right) \mathrm{Pt}-\mathrm{Tl}$ ", ${ }^{47,} 48$ " $\left(\mathrm{C}^{\wedge} \mathrm{C}\right) \mathrm{Pt}-\mathrm{Tl} \mathrm{I}^{29}$ or “( $\left.\mathrm{C}^{\wedge} \mathrm{N}\right) \mathrm{Pd}-\mathrm{Tl}$ " complexes. ${ }^{49}$ The $\mathrm{Pt}-\mathrm{Tl}$ lines are almost perpendicular to the best $\mathrm{Pt}$ square planes, such that the angles between the Pt...Tl vectors and perpendicular to the this plane are $8.5(1)^{\circ}$ and $9.0(1)^{\circ}$.
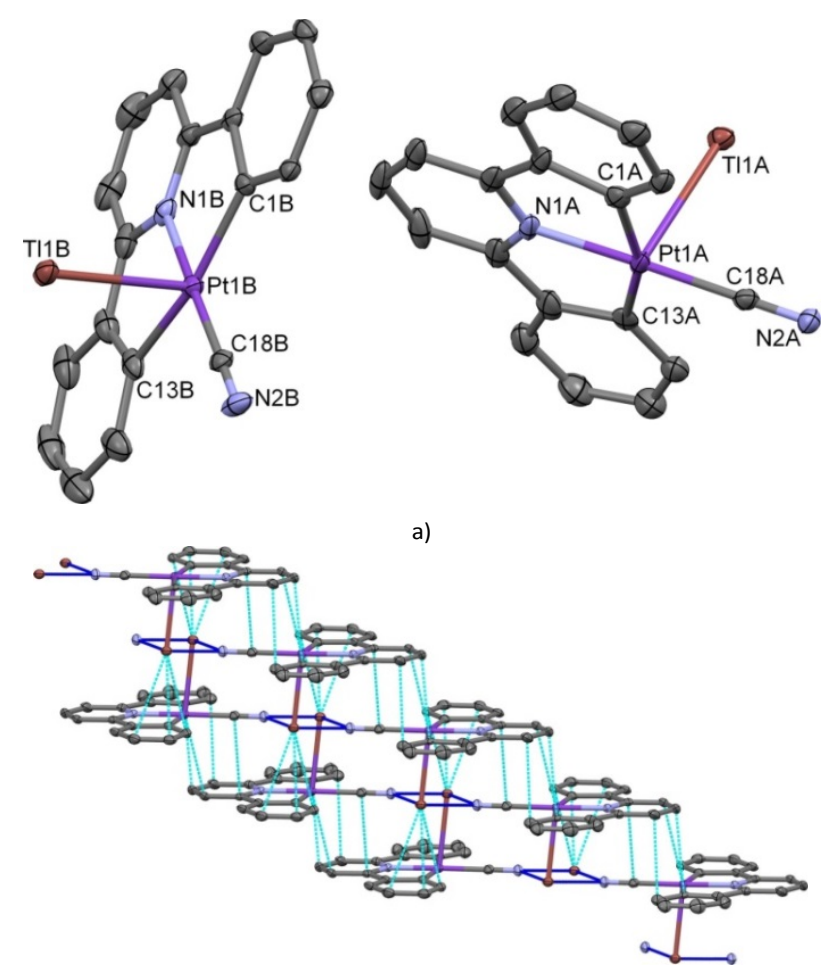

b)

Figure 6. a) Crystal structure of the two discrete $[\mathrm{PtTI}(\mathrm{CNC})(\mathrm{CN})]$ units found in the X-ray crystal structure of 8 . b) Supramolecular arrangement showing the

Both $[\mathrm{PtTI}(\mathrm{CNC})(\mathrm{CN})]$ moieties form supramolecular entities by means of Tl-N interactions (see Figure $6 \mathrm{~b}$ ). The $\mathrm{Tl}$ atoms are at contact distances from $\mathrm{N}$ atoms of the cyano ligands of neighbour complexes ( $\mathrm{Tl}-\mathrm{N}=2.636(4)-2.683(5))$. At the same 
time, each $\mathrm{N}$ atom is contacting two different $\mathrm{Tl}$ centres. The cyano bridging mode $\mu_{3}-\mathrm{KC}: \mathrm{KN}: \mathrm{KN}$ is not very common and has only previously been reported in the cis- and trans$\left[\mathrm{PtTl}_{2}\left(\mathrm{C}_{6} \mathrm{~F}_{5}\right)_{2}(\mathrm{CN})_{2}\right]$ complexes, in which the TI-N distances are slightly longer than in $8 .^{47}$ As a result of these interactions, 8 shows a one-dimensional supramolecular framework as can be seen in Figure $6 \mathrm{~b}$. Other supramolecular structures have been found in similar Pt or Pd cyano complexes containing $\mathrm{Pt}(\mathrm{II})-$ $\mathrm{Tl}(\mathrm{I})$ or $\mathrm{Pd}(\mathrm{II})-\mathrm{Tl}(\mathrm{I})$ bonds. ${ }^{48,}{ }^{49}$ Moreover, the supramolecular arrangement of $\mathbf{8}$ can be described as a sort of "stair", in such a way that all the steps are parallel, resulting in $\pi \cdots \pi$ interactions between the aromatic rings of CNC ligands (C-C distances 3.32-3.38 ̊̊) and long $n$-arene-TI (around $3.45 \AA$ ) interactions.

The dark brown solid obtained from the reaction of $\left(\mathrm{NBu}_{4}\right)[\mathrm{Pt}(\mathrm{CNC})(\mathrm{S}-2 \mathrm{py})]$ with $\mathrm{TIPF}_{6}$ is soluble enough in common solvents as to be studied by NMR spectroscopy. The ${ }^{1} \mathrm{H}$ NMR spectrum of solutions of this solid in $\mathrm{CD}_{2} \mathrm{Cl}_{2}$ (see Figure S19, Supporting Information) shows the signals corresponding to the $\mathrm{NBu}_{4}{ }^{+}$cation and a set of signals in the aromatic region caused by the CNC and S-2py ligands. However, these signals appear at different chemical shifts than in the starting material, and their integration with respect to the cation ones is consistent with the formula $\left(\mathrm{NBu}_{4}\right)\left[\{\mathrm{Pt}(\mathrm{CNC})(\mathrm{S}-2 \mathrm{py})\}_{2} \mathrm{TI}\right]$ (9) for this solid. The aromatic signals were assigned on the basis of a two-dimensional COSY $\left({ }^{1} \mathrm{H}-{ }^{1} \mathrm{H}\right)$ experiment (see Figure $\mathrm{S} 2 \mathrm{O}$, Supporting Information). Due to a relatively low solubility, the ${ }^{1} \mathrm{H}$ NMR spectra at lower temperatures are less defined, but basically they keep showing that there is one kind of S-2py and CNC ligands, that each maintain the equivalence of both halves.

It has been reported that in some complexes containing Pt-TI bonds, there are equilibria in solution that involve the cleavage and formation of the intermetallic bond, such as the one represented below, that are faster than the NMR time of response. ${ }^{27,28}$

$$
\text { "Pt-Tl-Pt" } \rightleftharpoons \text { "Pt-Tl" + "Pt" }
$$

These equilibria are also observed in solutions of complex $\mathbf{9}$, which supports the idea that there are Pt-Tl bonds in solution. Thus, the ${ }^{1} \mathrm{H}$ NMR spectrum of a solution of 9 to which a small amount of the starting material $\left(\mathrm{NBu}_{4}\right)[\mathrm{Pt}(\mathrm{CNC})(\mathrm{S}-2 \mathrm{py})](3)$ has been added shows no signals of this starting material, but only one set of signals. These appear at slightly different ppm than the original signals of 9, especially the ones corresponding to H3S-2py and H4S-2py (see Figure S21, Supporting Information). This observation is in agreement with the equilibrium above, and the addition of some amount of the starting material would cause a displacement of the equilibrium to the left.

It was possible to obtain crystals from solutions of $\mathbf{9}$ in $\mathrm{CH}_{2} \mathrm{Cl}_{2}$, suitable for their study by $\mathrm{X}$-ray diffraction. The determined structure confirms the trinuclear $\mathrm{Pt}_{2} \mathrm{TI}$ nature of complex 9 (see Figure 7 and Table S7, Supporting Information).

The trinuclear complex has a "sandwich" type structure in such a way that the $\mathrm{TI}$ centre lies between two "Pt(CNC)(S-2py)" units. The thallium atom is bonded to the two platinum centres with Pt-TI distances of 2.8953(2) and 2.9184(2) A.. No $\mathrm{Tl}^{-\mathrm{C}_{\text {ipso }}}$ (CNC) interaction is present. The $\mathrm{Pt}-\mathrm{Tl}$ distances are similar to other Pt-Tl-Pt sandwich complexes such as $\left(\mathrm{NBu}_{4}\right)\left[\left\{\mathrm{Pt}\left(\mathrm{C}_{6} \mathrm{~F}_{5}\right)_{2}(\mathrm{bzq})\right\}_{2} \mathrm{Tl}\right]$ (range 2.8747(3)-2.9432(4) $\AA$ ) and $\left(\mathrm{NBu}_{4}\right)\left[\left\{\mathrm{Pt}\left(\mathrm{C}_{6} \mathrm{~F}_{5}\right)_{2}(\mathrm{bzq})\right\}_{2} \mathrm{Tl}(\mathrm{THF})\right](2.9352(6), 2.9705(6) \AA)(\mathrm{bzq}=$ 7,8-benzoquinolate). ${ }^{27}$ The $\mathrm{Pt}-\mathrm{Tl}-\mathrm{Pt}$ line is rather straight ( $\mathrm{Pt}(1)-\mathrm{Tl}-\mathrm{Pt}(2)$ angle $\left.165.58(1)^{\circ}\right)$ with the $\mathrm{Pt}-\mathrm{Tl}$ vectors being almost perfectly perpendicular to the best $\mathrm{Pt}$ square planes (angles of the vectors and the perpendicular to this plane are only $3.8(1)^{\circ}$ and $\left.3.6(1)^{\circ}\right)$. The S-2py ligands are acting as bridges between the metal centres, with the $\mathrm{S}$ atoms coordinated to Pt, and distances TI-N somewhat long (2.671(4) $\AA$ and $2.710(4) \AA$ ) , but in the range found in similar bonds. ${ }^{50}$ Unlike to $\left[\{\mathrm{Pt}(\mathrm{CNC})(\mathrm{S}-2 \mathrm{py})\}_{2} \mathrm{Ag}_{2}\right]$ (5), no changes in the coordination mode of the S-2py ligand with respect to the starting material $\mathbf{3}$ are observed in $\mathbf{9}$.

Finally, the $\left[\{\mathrm{Pt}(\mathrm{CNC})(\mathrm{S}-2 \mathrm{py})\}_{2} \mathrm{Tl}\right]^{-}$anions establish $\pi \cdots \pi$ interactions with the aromatic rings of the CNC ligands of neighbour complexes $(C \cdots C \approx 3.4 \AA$ ) forming a supramolecular chain (see Figure S22, Supporting Information). ${ }^{28}$

\section{Preparation of [PtTI(CNC)(S-2py)] (10)}

The different $\mathrm{Pt} / \mathrm{Tl}$ ratio obtained in the products from the reactions of the starting materials $\left(\mathrm{NBu}_{4}\right)[\mathrm{Pt}(\mathrm{CNC}) \mathrm{X}]$ with $\mathrm{TIPF}_{6}$ is noteworthy. Thus, when $\mathrm{X}=\mathrm{Cl}$ or $\mathrm{CN}, 1: 1$ complexes 7 and 8 are obtained, while when $\mathrm{X}=\mathrm{S}-2 \mathrm{py}$, a 2:1 ratio is obtained in $\mathbf{9}$. This may be related to the ability of the S-2py ligand to effectively bridge two metal centres which, at the same time, could be bonded through a strong, perpendicular $\mathrm{Pt}-\mathrm{Tl}$ bond. This arrangement would be much more difficult for $\mathrm{X}=\mathrm{Cl}$ and virtually impossible for $\mathrm{X}=\mathrm{CN}$ for geometric reasons.

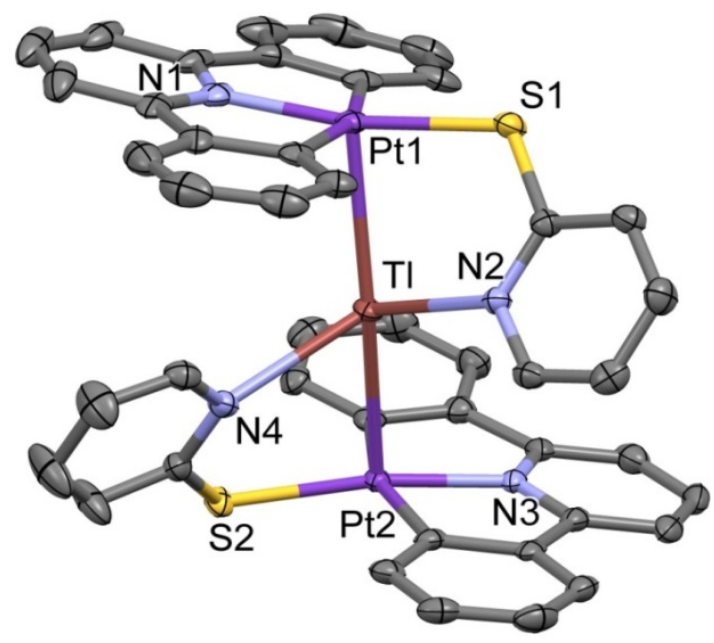

Figure 7. X-ray crystal structure of the complex anion of the structure $\left(\mathrm{NBu}_{4}\right)\left[\{\mathrm{Pt}(\mathrm{CNC})(\mathrm{S}-2 \mathrm{py})\}_{2} \mathrm{TI}\right] \cdot \mathrm{CH}_{2} \mathrm{Cl}_{2}(9)$.

However, we explored other starting materials in order to achieve the synthesis of a 1:1 Pt/TI S-2py complex similar to 7 or 8. Thus, we reacted $[\mathrm{Pt}(\mathrm{CNC})(\mathrm{dmso})]$ with $[\mathrm{TI}(\mathrm{S}-2 \mathrm{py})]$. This thallium compound was prepared in situ by adding $\mathrm{Tl}$ (acac) to a pyridine-2-thiol solution (1:1 ratio) in $\mathrm{CH}_{2} \mathrm{Cl}_{2}$. The resulting 
solution is stirred for $35 \mathrm{~min}$ and then [Pt(CNC)(dmso)] (1:1) was added, allowing the mixture further stirring for $10 \mathrm{~min}$. The solution was concentrated to ca. $2 \mathrm{~mL}$ and the addition of $\mathrm{n}$-hexane caused the precipitation of a brown solid that was filtered off. Spectroscopical and analytical data for this solid are consistent with a formula [PtTI(CNC)(S-2py)] (10).

The most remarkable feature of the ${ }^{1} \mathrm{H}$ NMR spectrum of a solution of 10 in $\mathrm{CD}_{2} \mathrm{Cl}_{2}$ at room temperature (see Figure $\mathrm{S} 24$, Supporting Information) is the downfield displacement of the $\mathrm{H} 2$ signal of the CNC ligand (see Chart 1 for the NMR atom numbering scheme) $0.45 \mathrm{ppm}$, with respect to the analogous signal in the starting material. Remarkably, the ${ }^{1} \mathrm{H} N M R$ spectrum in dmso- $d_{6}$ is also different from the ones obtained for $[\mathrm{Pt}(\mathrm{CNC})(\mathrm{dmso})]$ or the mononuclear [Pt(CNC)(S-2py)] (see Figure S25, Supporting Information) which indicates that, if formed, the Pt-TI bond would survive to some extent in donor solvents such as dmso.

The existence of equilibria in solutions of $\mathbf{1 0}$, analogous to the ones proposed above for $\mathbf{9}$, has also been investigated. Also in this case, the addition of small amounts of $\left(\mathrm{NBu}_{4}\right)[\mathrm{Pt}(\mathrm{CNC})(\mathrm{S}-$ 2py)] (3) to solutions of 10 in $\mathrm{CD}_{2} \mathrm{Cl}_{2}$ does not cause the appearance of signals for the former in their ${ }^{1} \mathrm{H}$ NMR spectra, but the resultant signals appear at values of chemical shift intermediate between the two. This is consistent with the presence of such equilibria, faster than the NMR time of response.

By recrystallizing the solid $\mathbf{1 0}$ (see Experimental section) it was possible to obtain crystals that were studied by X-ray diffraction. The structure determined confirms the presence of Pt-Tl bonds (see Figure 8 and Table S8, Supporting Information).

Three "PtTl" units with different structural roles lie in the asymmetric part of the unit cell. Thus, $\mathrm{Pt}(1), \mathrm{Pt}(2), \mathrm{TI}(1)$ and $\mathrm{TI}(2)$ form a discrete tetranuclear unit (see Figure $8 \mathrm{~b}$ ). $\mathrm{TI}(2)$ is simultaneously bonded to the two $\mathrm{Pt}$ atoms with $\mathrm{Pt}-\mathrm{Tl}$ distances of 2.9991(9) and 2.8222(9) $\AA$, while $\mathrm{TI}(1)$ is only bonded to $\mathrm{Pt}(1)$ with a distance $2.8324(9) \AA$. The $\mathrm{TI}(1)-\mathrm{Pt}(1)-\mathrm{TI}(2)$ and $\mathrm{Pt}(2)-\mathrm{TI}(2)-\mathrm{Pt}(1)$ are 158.64(3) ${ }^{\circ}$ and $155.90(3)^{\circ}$ respectively. Besides, the S-2py ligands act as bridges between the $\mathrm{Pt}$ and $\mathrm{Tl}$, always with the $\mathrm{S}$ atom coordinated to $\mathrm{Pt}$ and the $\mathrm{N}$ atom to $\mathrm{TI}$.

On the other hand, $\mathrm{Pt}(3)$ and $\mathrm{Tl}(3)$ are forming an infinite -Pt-TI-Pt-Tl- linear chain (see Figure 8c). The Pt(3)-TI(3) distances are 2.9183(9) and 2.8839(9) $\AA$. The angles involving the metals are $\mathrm{Tl}(3)-\mathrm{Pt}(3)-\mathrm{TI}(3) \quad 161.48(3)^{\circ}$ and $\mathrm{Pt}(3)-\mathrm{Tl}(3)-\mathrm{Pt}(3) 144.30(3)^{\circ}$. Again, the pyridine-2-thiolate is bridging both metallic centres.

The tetranuclear subunit interacts with the chain through intermolecular TI...S contacts (in red in Figure 8a), with TI-S

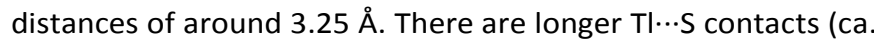
$3.81 \AA$ ) between different tetranuclear subunits (in cyan in Figure 8a).

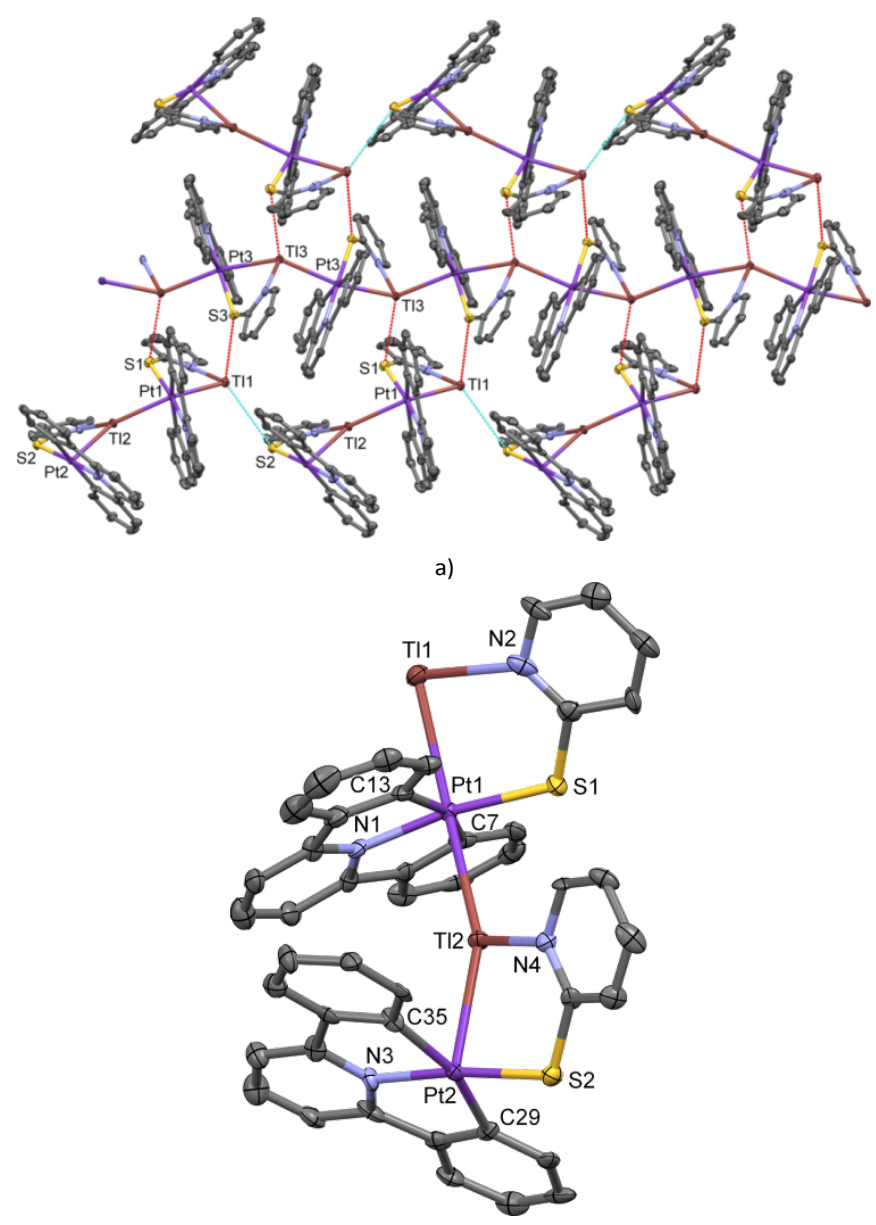

b)

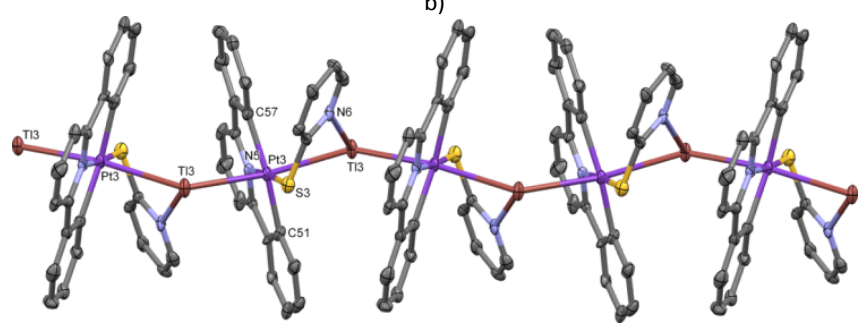

c)

Figure 8. a) X-ray crystal structure of $[\mathrm{PtTI}(\mathrm{CNC})(\mathrm{S}-2 \mathrm{py})](\mathbf{1 0})$. b) View of the tetranuclear subunit. c) View of the infinite chain.

\section{Discussion}

$P t-A g$ complexes. The common motif found in the structures of $\mathbf{4}$ and $\mathbf{5}$ is the tetranuclear " $\mathrm{Pt}_{2} \mathrm{Ag}_{2}$ " core. Very few structures with this disposition of the metal centres have been reported so far: trans- $\left[\left\{\mathrm{PtAg}\left(\mathrm{C}_{6} \mathrm{~F}_{5}\right)_{2} \mathrm{Cl}_{2}\right\}_{2}\right]^{2-51}$, $\left[\left\{\left(\mathrm{C}_{8} \mathrm{H}_{6} \mathrm{~N}_{2} \mathrm{Cl}_{4}\right) \mathrm{Me}_{2} \mathrm{PtAg}\left(\mathrm{SO}_{3} \mathrm{CF}_{3}\right)\right\}_{2}\right]{ }^{25} \quad[\{\mathrm{PtAg}(\mathrm{bzq}) \mathrm{Me}-$ $\left.\left.\left(\mathrm{PPh}_{2} \mathrm{C}_{6} \mathrm{H}_{5} \mathrm{~N}\right)\right\}_{2}\right]^{2+}, \mathrm{C}^{2} \quad\left[\left\{\left(\mathrm{C}_{6} \mathrm{~F}_{5}\right)_{2}(\mathrm{acac}) \operatorname{PtAg}\left(\mathrm{CH}_{2} \mathrm{Cl}_{2}\right)\right\}_{2}\right]^{2-53}$ and $\left[\left\{\mathrm{PtAg}(\text { bipy })\left(\mathrm{C}_{6} \mathrm{H}_{4} \mathrm{~S}_{2}\right)\right\}_{2}\right]^{2+54}$. Some of these complexes show some asymmetry in the " $\mathrm{Pt}_{2} \mathrm{Ag}_{2}$ " core with a pair of $\mathrm{Pt}-\mathrm{Ag}$ distances significantly longer that the other two and in all cases the silver centres are also bonded to other atoms, either from a ligand of the coordination sphere of the Pt atom, thus acting as a bridge, or from an "external" ligand, frequently a solvent molecule of an anion (or both).

It is noteworthy that the reactions of the neutral analogous products $[\mathrm{Pt}(\mathrm{CNC}) \mathrm{L}]\left(\mathrm{L}=\right.$ dmso, $\left.\mathrm{PPh}_{3}, \mathrm{SC}_{4} \mathrm{H}_{8}\right)$ with $\mathrm{AgClO}_{4}$ yield 
the trinuclear sandwich complexes $\left[\{\mathrm{Pt}(\mathrm{CNC}) \mathrm{L}\}_{2} \mathrm{Ag}\right]^{+}$, even when the reaction is attempted in an equimolar $\mathrm{Pt}: \mathrm{Ag}$ ratio. ${ }^{24}$ The reason for the anionic starting materials giving crystal structures with " $\mathrm{Pt}_{2} \mathrm{Ag}_{2}$ " cores, while the neutral produce " $\mathrm{Pt}_{2} \mathrm{Ag}$ " ones could be the increase of the electron density on the Pt fragment in the former because of its anionic nature. Thus, the higher basicity of the platinum enables it to "trap" two acidic Ag centres between the planar Pt fragments.

Regarding the differences in the insolubility of the solids 4 and 5, they may be related to the different abilities of the $\mathrm{Cl}, \mathrm{CN}$ or $\mathrm{S}-2$ py ligands to bridge the $\mathrm{Pt}$ and $\mathrm{Ag}$ centres, which in turn affects to the overall nuclearity of the resulting complexes. The ability of the cyano ligand to act as a linear $\mu_{2}-\mathrm{kC}: \mathrm{kN}$ bridge leads to the formation of the octanuclear complex as found in the structure 4 by coupling two " $\mathrm{Pt}_{2} \mathrm{Ag}_{2}$ " units. In contrast, the $\mathrm{S}-2$ py ligand can act as a bridge between Pt and $\mathrm{Ag}$ of the same " $\mathrm{Pt}_{2} \mathrm{Ag}_{2}$ " unit, giving rise to complex found in $\mathbf{5}$ that is "only" tetranuclear.

When the silver starting material has a triphenylphosphane attached the reactions with $\mathbf{1}$ and $\mathbf{3}$ take place with an interchange of ligands, and rendering $\left[\mathrm{Pt}(\mathrm{CNC})\left(\mathrm{PPh}_{3}\right)\right]$ and $\mathrm{AgCl}$ for 1 and the tentative "Ag(S-2py)" complexes for $\mathbf{3}$. Scheme 2 proposes two possible routes through which this ligand interchange could take place in solution. However, the reaction with the cyano starting material $\mathbf{2}$ eventually yields crystals (6) in which a stable Pt-Ag product, namely $\left[\{\mathrm{Pt}(\mathrm{CNC})(\mu-\mathrm{CN})\}_{2}\left\{\mathrm{Ag}\left(\mathrm{PPh}_{3}\right)\right\}_{2}\right]$ is present. This is likely due to the impossibility of the $\mathrm{CN}$ ligand to establish interaction with the same Ag centre bonded to the Pt to which it is coordinated due to its linear nature. Since the interchange of ligands cannot progress in this case, the stable tetranuclear complex found in $\mathbf{6}$ can be isolated.

The presence of $\mathrm{Pt}-\mathrm{M}^{10-12}$ or $\mathrm{Pd}-\mathrm{M}^{13,14}(\mathrm{M}=\mathrm{Ag}, \mathrm{Au}, \mathrm{Cu})$ species has been postulated or detected in transmetalation and ligand interchange processes of great interest in cooperative catalysis. ${ }^{55}$ A similar CNC complex containing Pt-M bonds $(M=A g, A u)$ has been proposed as snapshots of such
Pt-TI complexes. The systematization of the structures determined from recrystallization of the solids obtained in the reaction of the Pt starting materials with $\mathrm{TI}(\mathrm{I})$ salts is more complicated. $\mathrm{Pt}(\mathrm{II}) \rightarrow \mathrm{TI}(\mathrm{I})$ heteropolynuclear clusters have been reported to present a wide array of structures: di (PtTI), ${ }^{26,48,56-}$ ${ }^{59}$ tri $\left(\mathrm{PtTl}_{2},{ }^{60-63} \mathrm{Pt}_{2} \mathrm{Tl}^{27,} 29,45,64-67\right)$, tetra ("paired" $(\mathrm{PtTI})_{2},{ }^{47,48,68-}$ ${ }^{71}$ trigonal $\left.\mathrm{Pt}_{3} \mathrm{Tl}^{28,}{ }^{24}\right)$, hexanuclear clusters $\left(\mathrm{Pt}_{2} \mathrm{Tl}_{4},{ }^{46} \mathrm{Pt}_{3} \mathrm{Tl}_{3}{ }^{28}\right)$, or infinite chains or networks. ${ }^{26,27,45,47,66,71-73}$ In the case of 7 and $\mathbf{1 0}$ even two different structural arrangements are present in the same crystal structure. Thus, for $\mathbf{7}$, a linear infinite chain solely supported by Pt-TI bonds coexists with discrete "PtTl" units. Similarly, in $\mathbf{1 0}$ a similar linear chain shares the same crystal with discrete tetranuclear linear " $\mathrm{Pt}_{2} \mathrm{Tl}_{2}$ " moieties. In both structures, as well as in $\mathbf{8}$, there are secondary interactions, in which the TI centres participate, that join the different structural motifs giving rise to elaborate supramolecular patterns.

The only discrete $\mathrm{Pt}-\mathrm{Tl}$ complex whose structure has been determined is the trinuclear $\left(\mathrm{NBu}_{4}\right)\left[\{\mathrm{Pt}(\mathrm{CNC})(\mathrm{S}-2 \mathrm{py})\}_{2} \mathrm{Tl}\right]$ present in 9, even when the $\mathrm{Pt} / \mathrm{Tl}$ ratio used for the starting materials is $1: 1$. It is noteworthy that the expected S-2py $1: 1$ complex in $\mathbf{1 0}$ is only obtained through a different path that involves the previous formation in situ of [TI(S-2py)], and that involves the breaking of a TI-S bond and the formation of a $\mathrm{Pt}-\mathrm{S}$ one. Similar results have been reported in the reactions of [TI(S-2py)] with [Pt $\left.\left(\mathrm{C}_{6} \mathrm{~F}_{5}\right)\left(\mathrm{C}^{\wedge} \mathrm{N}\right)(\mathrm{S})\right]\left[\mathrm{C}^{\wedge} \mathrm{N}=\mathrm{ppy}\right.$, bzq; $\mathrm{S}=$ dmso, $\left.\mathrm{Me}_{2} \mathrm{CO}\right),{ }^{26}$ which give discrete $\left[\left(\mathrm{C}_{6} \mathrm{~F}_{5}\right)\left(\mathrm{C}^{\wedge} \mathrm{N}\right)(\mathrm{S}-2 \mathrm{py}) \mathrm{PtTl}\right]$, with a bridging $\mathrm{S}-2 \mathrm{py}$ ligand $\mathrm{S}$ - bonded to $\mathrm{Pt}$ and $\mathrm{N}$ - bonded to Tl. However, the use of the related [ $\mathrm{TI}\left(\mathrm{S}-2 \mathrm{py}-\mathrm{CF}_{3}\right)$ ] starting material give 1:1 $\mathrm{Pt}-\mathrm{Tl}$ chains in which either the $\mathrm{S}$ atoms are bridging both metal atoms or the $\mathrm{S}-2 \mathrm{py}-\mathrm{CF}_{3}$ ligand is not acting as a bridge at all. ${ }^{26}$

From all these observations, it seems that the geometry adopted by $\mathrm{Pt}-\mathrm{Tl}$ complexes can be very varied. Factors such as the possibility of the ligands to act as a bridge, the existence of secondary interactions or even the packing forces in the crystal environment play a very important and unpredictable

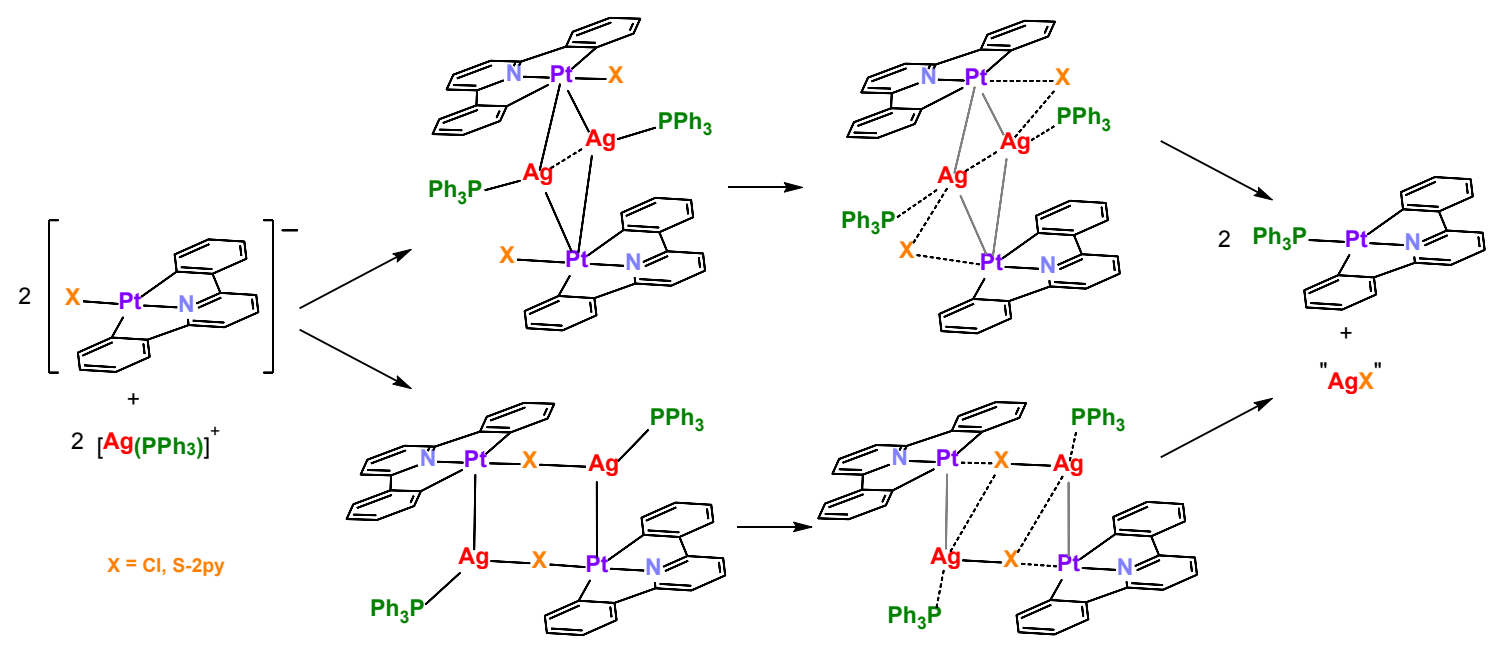

Scheme 2. Possible routes of ligand interchange between $[\mathrm{Pt}(\mathrm{CNC}) \mathrm{X}]^{-}$and $\left[\mathrm{Ag}\left(\mathrm{PPh}_{3}\right)\right]^{+}$in solution

transmetalation mechanisms. ${ }^{20,24}$

role in the final structure. This may be related with the 
dynamic behaviour of the Pt-TI complexes in solution, for which, as mentioned above, equilibria involving cleavage and re-formation of the intermetallic bonds are detected.

In any case, a remarkable difference between the $\mathrm{Pt}-\mathrm{Ag}$ and the Pt-Tl complexes, not only described here, but also in the literature, is that the former exhibit interactions of the silver centre with the ipso carbon atoms of the CNC (or other cyclometalated planar ligands such as bzq or phpy), ${ }^{21-24,39,44,52,}$ ${ }^{74,75}$ while the $\mathrm{Tl}$ complexes never show something similar. ${ }^{26-28}$

\section{Conclusions}

The anionic complexes $\left(\mathrm{NBu}_{4}\right)[\mathrm{Pt}(\mathrm{CNC}) \mathrm{X}], \mathbf{1 - 3}$, can be used successfully to prepare heteropolynuclear complexes with $\mathrm{Pt} \rightarrow \mathrm{Ag}$ or $\mathrm{Pt} \rightarrow \mathrm{Tl}$ dative bonds. However, their negative charge does not appear to dramatically affect the stability of the complexes formed or the strength of the intermetallic interactions. Similar Pt-Ag or Pt-Tl bond distances are found in structures of complexes in which the platinum centre is part of a neutral precursor. A more important factor seems to be the nature of the ligand attached to the " $\mathrm{Pt}(\mathrm{CNC})$ " fragment. Thus, the geometry of this ligand, and the disposition of its potentially donor atoms is the key feature for the adopted crystal structure. In the case of $\mathrm{CN}$, its linear bridging feature causes higher nuclearity complexes since it is only able to connect atoms of different "Pt-M" units. On the other hand, the pyridine-2-thiolate ligand, with two different potential donor atoms and an intrinsic greater flexibility, can bridge metal atoms of the same "Pt-M" resulting in lower nuclearities.

In the case of the $\mathrm{Tl}$ complexes, the structural complexity increases. Even in the same crystal, similar "Pt-Tl" units can adopt different structural roles. This might due to the apparent lability of the $\mathrm{Pt} \rightarrow \mathrm{Tl}$ bonds, as it is pointed out in the equilibria detected in solution, and the ability of the thallium center to establish secondary interactions with donor atoms or aromatic $\pi$ electron density from neighboring moieties. The sum of all these relatively weak interactions, along with other packing forces present in the crystal, could be the reason for which a particular structural arrangement is adopted.

\section{Experimental}

\section{General considerations.}

A modification of the method reported in the literature ${ }^{28}$ was used to prepare the starting material $[\mathrm{Pt}(\mathrm{CNC})(\mathrm{dmso})]$ (-CNC- = 2,6-di(phen-2-ide)-pyridine) (see below). $\left(\mathrm{NBu}_{4}\right)[\mathrm{Pt}(\mathrm{CNC})(\mathrm{S}-$ $2 p y)$ ] (3) was also prepared following the method reported in the literature. ${ }^{35}$ Elemental analyses were carried out with a Perkin-Elmer 2400 CHNS analyser. IR spectra were recorded on a Perkin-Elmer Spectrum 100 FT-IR spectrometer (ATR in the range $250-4000 \mathrm{~cm}^{-1}$ ). Mass spectrometry was performed with the Microflex matrix-assisted laser desorption ionization-timeof-flight (MALDI-TOF) Bruker, an Autoflex III MALDI-TOF Bruker or Esquire $3000+$ Bruker instruments. ${ }^{1} \mathrm{H},{ }^{13} \mathrm{C},{ }^{31} \mathrm{P}$ and ${ }^{195} \mathrm{Pt}\left\{{ }^{1} \mathrm{H}\right\}$ NMR spectra were recorded on a Bruker AV-400, AV-300 or ARX-300 spectrometer using the standard references: $\mathrm{SiMe}_{4}$ for ${ }^{1} \mathrm{H}, \mathrm{CFCl}_{3}$ for ${ }^{13} \mathrm{C}, 85 \% \mathrm{H}_{3} \mathrm{PO}_{4}$ for ${ }^{31} \mathrm{P}$ and $\mathrm{Na}_{2} \mathrm{PtCl}_{6}$ in $\mathrm{D}_{2} \mathrm{O}$ for the ${ }^{195} \mathrm{Pt}$.

Safety note. Perchlorate salts of metal complexes with organic ligands are potentially explosive. Only small amounts of material should be prepared and these should be handled with great caution.

\section{Preparation of $\left(\mathrm{NBu}_{4}\right)[\mathrm{Pt}(\mathrm{CNC}) \mathrm{Cl}](1)$.}

To a solution of $[\mathrm{Pt}(\mathrm{CNC})(\mathrm{dmso})](0.100 \mathrm{~g}, 0.199 \mathrm{mmol})$ in $\mathrm{MeOH}(25 \mathrm{~mL})$ at room temperature, $\mathrm{NBu}_{4} \mathrm{Cl}(0.066 \mathrm{~g}, 0.239$ $\mathrm{mmol}$ ) was added. After 4 days of stirring the reaction mixture under an Ar atmosphere, the solution was evaporated to dryness. The resulting solid was stirred with $15 \mathrm{~mL}$ of $\mathrm{MeOH}$ for 5 minutes and the mixture was again evaporated. Diethyl ether $(10 \mathrm{~mL})$ was added on the orange solid precipitate which appeared, and the resulting suspension was filtered off, washed three times with diethyl ether $(5 \mathrm{~mL})$ and air dried (0.117 g, $84 \%)$.

Anal. Found: $\mathrm{C}, 56.09 ; \mathrm{H}, 6.56 ; \mathrm{N}, 4.15$. Calcd for $\mathrm{C}_{33} \mathrm{H}_{47} \mathrm{ClN}_{2} \mathrm{Pt}$ : C, 56.44.; H, 6.75; N, 3.99. IR $\left(\mathrm{U}_{\max } / \mathrm{cm}^{-1}\right): 1593(\mathrm{~m}, \mathrm{NC}), 1575$ $(\mathrm{w}, \mathrm{NC}), 1556(\mathrm{w}, \mathrm{NC}), 1538(\mathrm{w}, \mathrm{NC}), 886\left(\mathrm{~m}, \mathrm{NBu}_{4}{ }^{+}\right), 319$ (s, PtCl). ${ }^{1} \mathrm{H}$ NMR (400.132 MHz, $\mathrm{CD}_{2} \mathrm{Cl}_{2}, 298 \mathrm{~K}$. See Chart 1 for the $\mathrm{H}$ numbering scheme): $\delta=7.83\left(2 \mathrm{H}, \mathrm{dd},{ }^{3} J_{\mathrm{H} 2-\mathrm{H} 3}=7.3 \mathrm{~Hz},{ }^{4} J_{\mathrm{H} 2-\mathrm{H} 4}=\right.$ $\left.1.0 \mathrm{~Hz},{ }^{3} J_{\mathrm{H} 2-\mathrm{Pt}}=23.7 \mathrm{~Hz}, \mathrm{H} 2\right), 7.50\left(1 \mathrm{H}, \mathrm{t},{ }^{3} J_{\mathrm{H} 7-\mathrm{H} 6}=7.9 \mathrm{~Hz}, \mathrm{H} 7\right)$, $7.37\left(2 \mathrm{H}, \mathrm{dd},{ }^{3} \mathrm{~J}_{\mathrm{H} 5-\mathrm{H} 4}=7.5 \mathrm{~Hz},{ }^{4} J_{\mathrm{H} 5-\mathrm{H} 3}=1.0 \mathrm{~Hz}, \mathrm{H} 5\right), 7.23(2 \mathrm{H}, \mathrm{td}$, $\left.{ }^{3} J_{\mathrm{H} 3-\mathrm{H} 4}={ }^{3} \mathrm{~J}_{\mathrm{H} 3-\mathrm{H} 2}=7.3 \mathrm{~Hz},{ }^{4} \mathrm{~J}_{\mathrm{H} 3-\mathrm{H} 5}=1.0 \mathrm{~Hz}, \mathrm{H} 3\right), 7.17\left(2 \mathrm{H}, \mathrm{d}^{3}{ }^{3} \mathrm{~J}_{\mathrm{H} 6-\mathrm{H} 7}=\right.$ $7.9 \mathrm{~Hz}, \mathrm{H} 6), 6.99\left(2 \mathrm{H}, \mathrm{td},{ }^{3} J_{\mathrm{H} 4-\mathrm{H} 3}={ }^{3} J_{\mathrm{H} 4-\mathrm{H} 5}=7.5 \mathrm{~Hz},{ }^{4} J_{\mathrm{H} 4-\mathrm{H} 2}=1.0\right.$ $\mathrm{Hz}, \mathrm{H} 4), 3.03\left(2 \mathrm{H}, \mathrm{t},{ }^{3} J_{\mathrm{H \alpha}-\mathrm{H} \beta}=7.5 \mathrm{~Hz}, \mathrm{H \alpha}\left(\mathrm{CH}_{2}-\mathrm{NBu}_{4}{ }^{+}\right)\right), 1.35(2 \mathrm{H}$, q, $\left.{ }^{3} J_{\mathrm{H} \beta-\mathrm{H \gamma}}={ }^{3} J_{\mathrm{H} \beta-\mathrm{H} \alpha} 7.5 \mathrm{~Hz}, \mathrm{H \beta}\left(\mathrm{CH}_{2}-\mathrm{NBu}_{4}{ }^{+}\right)\right), 1.17\left(2 \mathrm{H}\right.$, sext, ${ }^{3} J_{\mathrm{H \gamma}-\mathrm{H \beta}}$ $\left.={ }^{3} J_{\mathrm{H} \gamma-\mathrm{H} \delta}=7.5 \mathrm{~Hz}, \mathrm{H \gamma}\left(\mathrm{CH}_{2}-\mathrm{NBu}_{4}{ }^{+}\right)\right), 0.83\left(3 \mathrm{H}, \mathrm{t},{ }^{3} J_{\mathrm{H} \delta-\mathrm{H} \gamma}=7.5 \mathrm{~Hz}\right.$, $\left.\mathrm{H} \delta\left(\mathrm{CH}_{3}-\mathrm{NBu}_{4}{ }^{+}\right)\right) .{ }^{1} \mathrm{H}$ NMR $\left(400.132 \mathrm{MHz}, \mathrm{dmso}^{-\mathrm{d}_{6}}, 298 \mathrm{~K}\right): \delta=$ $7.84\left(1 \mathrm{H}, \mathrm{t},{ }^{3} \mathrm{~J}_{\mathrm{H} 7-\mathrm{H} 6}=7.8 \mathrm{~Hz}, \mathrm{H} 7\right), 7.77\left(2 \mathrm{H}, \mathrm{d}^{3}{ }^{3} \mathrm{H}_{\mathrm{H}-\mathrm{H} 3}=7.2 \mathrm{~Hz}\right.$, $\mathrm{H} 2), 7.65\left(2 \mathrm{H}, \mathrm{d},{ }^{3} \mathrm{~J}_{\mathrm{H} 6-\mathrm{H} 7}=7.8 \mathrm{~Hz}, \mathrm{H} 6\right.$, overlapped with $\left.\mathrm{H} 5\right), 7.64$ $\left(2 \mathrm{H}, \mathrm{d},{ }^{3} \mathrm{~J}_{\mathrm{H} 5-\mathrm{H} 4}=7.3 \mathrm{~Hz}, \mathrm{H} 5\right.$, overlapped with $\left.\mathrm{H} 6\right), 7.19(2 \mathrm{H}, \mathrm{t}$, $\left.{ }^{3} J_{\mathrm{H} 3-\mathrm{H} 4}={ }^{3} J_{\mathrm{H} 3-\mathrm{H} 5}=7.2 \mathrm{~Hz}, \mathrm{H} 3\right), 7.07\left(2 \mathrm{H}, \mathrm{t},{ }^{3} J_{\mathrm{H} 4-\mathrm{H} 3}={ }^{3} J_{\mathrm{H} 4-\mathrm{H} 5}=7.2 \mathrm{~Hz}\right.$, $\mathrm{H} 4), 3.15\left(2 \mathrm{H}, \mathrm{t},{ }^{3} J_{\mathrm{H} \alpha-\mathrm{H} \beta}=7.3 \mathrm{~Hz}, \mathrm{H \alpha}\left(\mathrm{CH}_{2}-\mathrm{NBu}_{4}{ }^{+}\right)\right), 1.55(2 \mathrm{H}, \mathrm{m}$, $\left.\mathrm{H \beta}\left(\mathrm{CH}_{2}-\mathrm{NBu}_{4}{ }^{+}\right)\right), 1.29\left(2 \mathrm{H}, \mathrm{sx},{ }^{3} J_{\mathrm{HY}-\mathrm{H} \beta}={ }^{3} \mathrm{~J}_{\mathrm{HY}-\mathrm{H} \delta}=7.3 \mathrm{~Hz}, \mathrm{HY}\left(\mathrm{CH}_{2}{ }^{-}\right.\right.$ $\left.\left.\mathrm{NBu}_{4}{ }^{+}\right)\right), 0.92\left(3 \mathrm{H}, \mathrm{t},{ }^{3} \mathrm{~J}_{\mathrm{H} \delta-\mathrm{Hy}}=7.3 \mathrm{~Hz}, \mathrm{H \delta}\left(\mathrm{CH}_{3}-\mathrm{NBu}_{4}{ }^{+}\right)\right) .{ }^{13} \mathrm{C}\left\{{ }^{1} \mathrm{H}\right\}$ NMR (100.624 MHz, $\left.\mathrm{CD}_{2} \mathrm{Cl}_{2}, 298 \mathrm{~K}\right): \delta=174.9$ (s, C1), 168.5 (s, C8), 149.3 (s, C9), 137.6 (s, C7), 135.5 (s, C2), 130.5 (s, C3), $123.2(\mathrm{~s}, \mathrm{C} 5), 122.5$ (s, C4), $113.8(\mathrm{~s}, \mathrm{C} 6) .{ }^{195} \mathrm{Pt}\left\{{ }^{1} \mathrm{H}\right\}$ NMR $(85.679$ $\mathrm{MHz}, \mathrm{CD}_{2} \mathrm{Cl}_{2}$ ): $\delta=-3506$ (br. s, $298 \mathrm{~K}$ ), -3545 (s, $\left.193 \mathrm{~K}\right) .{ }^{195} \mathrm{Pt}\left\{{ }^{1} \mathrm{H}\right\}$ NMR (64.324 MHz, dmso-d $\left.\mathrm{d}_{6}\right): \delta=-3937$ (s). Mass spectra MALDI- DIT: $\mathrm{m} / \mathrm{z}=460[\mathrm{Pt}(\mathrm{CNC})(\mathrm{Cl})]^{-}$.

\section{Preparation of $\left(\mathrm{NBu}_{4}\right)[\mathrm{Pt}(\mathrm{CNC})(\mathrm{CN})](2)$.}

This complex was prepared by a modified procedure. ${ }^{35}$ To a solution of $[\mathrm{Pt}(\mathrm{CNC})(\mathrm{dmso})](0.100 \mathrm{~g}, 0.199 \mathrm{mmol})$ in $\mathrm{CH}_{2} \mathrm{Cl}_{2}$ $(20 \mathrm{~mL})$ at room temperature, $\mathrm{NBu}_{4} \mathrm{CN}(0.063 \mathrm{~g}, 0.219 \mathrm{mmol})$ was added. After 30 minutes of stirring the reaction mixture, equal volume of water was then added and the mixture was vigorously stirred for $4 \mathrm{~min}$. More water was added $(20 \mathrm{~mL})$ and the upper (aqueous) layer was decanted. The methylene chloride solution was dried with $\mathrm{MgSO}_{4}$, filtered, and the filtrate was diluted with hexane $(20 \mathrm{~mL})$. The yellowish orange solid formed was filtered and air dried $(0.106 \mathrm{~g}, 77 \%)$.

Anal. Found: $\mathrm{C}, 58.72 ; \mathrm{H}, 6.84 ; \mathrm{N}, 6.12$. Calcd for $\mathrm{C}_{34} \mathrm{H}_{47} \mathrm{~N}_{3} \mathrm{Pt}$ : C, 58.94; H, 6.84; N, 6.06. IR $\left(\mathrm{U}_{\max } / \mathrm{cm}^{-1}\right): 2092(\mathrm{~m}, \mathrm{C} \equiv \mathrm{N}), 1596(\mathrm{~m}$, 
$\mathrm{NC}), 1575(\mathrm{w}, \mathrm{NC}), 1560(\mathrm{w}, \mathrm{NC}), 1541(\mathrm{w}, \mathrm{NC}), 880\left(\mathrm{~m}, \mathrm{NBu}_{4}{ }^{+}\right)$. ${ }^{195} \mathrm{Pt}\left\{{ }^{1} \mathrm{H}\right\}$ NMR $\left(85.679 \mathrm{MHz}, \mathrm{CD}_{2} \mathrm{Cl}_{2}\right): \delta=-4008(\mathrm{~s}, 298 \mathrm{~K}),-4033$ (s, $193 \mathrm{~K}) .{ }^{195} \mathrm{Pt}\left\{{ }^{1} \mathrm{H}\right\}$ NMR $\left(64.324 \mathrm{MHz}, \mathrm{dmso}^{-\mathrm{d}_{6}}\right.$ ): $\delta=-4008$ (s, $298 \mathrm{~K})$. Mass spectra MALDI- DIT: $\mathrm{m} / \mathrm{z}=450[\mathrm{Pt}(\mathrm{CNC})(\mathrm{CN})]^{-}$.

\section{Preparation of $\left[\{\mathrm{Pt}(\mathrm{CNC})(\mu-\mathrm{CN})\}_{4} \mathrm{Ag}_{4}\right](4)$.}

To a solution of $\left(\mathrm{NBu}_{4}\right)[\mathrm{Pt}(\mathrm{CNC})(\mathrm{CN})](0.050 \mathrm{~g}, 0.072 \mathrm{mmol})$ in acetone $(20 \mathrm{~mL})$ at room temperature and protected from light, $\mathrm{AgClO}_{4}$ (0.015 g, $0.072 \mathrm{mmol}$ ) was added. After 1 hour of stirring, the wine red solid formed was filtered, washed with nhexane $(5 \mathrm{~mL})$ and air dried $(0.037 \mathrm{~g}, 91 \%)$.

Anal. Found: C, 38.38; H, 2.43; N, 5.02. Calcd for $\mathrm{C}_{72} \mathrm{H}_{44} \mathrm{Ag}_{4} \mathrm{~N}_{8} \mathrm{Pt}_{4}: \mathrm{C}, 38.73 ; \mathrm{H}, 1.99 ; \mathrm{N}, 5.02 . \mathrm{IR}\left(\mathrm{U}_{\max } / \mathrm{cm}^{-1}\right): 2122$ $(m, C \equiv N), 1601(m, N C), 1576(w, N C), 1561(w, N C), 1545(w$, $\mathrm{NC})$.

\section{Preparation of $\left[\{\mathrm{Pt}(\mathrm{CNC})(\mathrm{S}-2 \mathrm{py})\}_{2} \mathrm{Ag}_{2}\right](5)$.}

To a solution of $\left(\mathrm{NBu}_{4}\right)[\mathrm{Pt}(\mathrm{CNC})(\mathrm{S}-2 \mathrm{py})](0.080 \mathrm{~g}, 0.10 \mathrm{mmol})$ in acetone $(20 \mathrm{~mL})$ at room temperature and protected from light, $\mathrm{AgClO}_{4}(0.021 \mathrm{~g}, 0.10 \mathrm{mmol})$ was added. After 30 minutes of stirring, the reaction mixture was evaporated to dryness. The orange solid formed was extracted with iPrOH $(10 \mathrm{~mL})$, filtered, washed with $\mathrm{n}$-hexane $(5 \mathrm{~mL})$ and air dried $(0.030 \mathrm{~g}$, 45\%).

Anal. Found: $\mathrm{C}, 41.07 ; \mathrm{H}, 2.85 ; \mathrm{N}, 4.25 ; \mathrm{S}, 4.85$. Calcd for $\mathrm{C}_{44} \mathrm{H}_{30} \mathrm{Ag}_{2} \mathrm{~N}_{4} \mathrm{Pt}_{2} \mathrm{~S}_{2}: \mathrm{C}, 41.13 ; \mathrm{H}, 2.35 ; \mathrm{N}, 4.36 ; \mathrm{S}, 4.99$. IR $\left(u_{\max } / \mathrm{cm}^{-1}\right): 1595(\mathrm{~m}, \mathrm{NC}), 1576(\mathrm{~m}, \mathrm{NC}), 1558(\mathrm{w}, \mathrm{NC}), 1540$ (w, NC).

Mass spectra ESI+: $\mathrm{m} / \mathrm{z}=1285\left[\left[\{\mathrm{Pt}(\mathrm{CNC})(\mathrm{S}-2 \mathrm{py})\}_{2} \mathrm{Ag}_{2}\right]+\mathrm{H}\right]^{+}$.

\section{Preparation of $\left[\{\mathrm{Pt}(\mathrm{CNC})(\mu-\mathrm{CN})\}_{2}\left\{\mathrm{Ag}\left(\mathrm{PPh}_{3}\right)\right\}_{2}\right](6)$.}

To a solution of $\left(\mathrm{NBu}_{4}\right)[\mathrm{Pt}(\mathrm{CNC})(\mathrm{CN})](0.059 \mathrm{~g}, 0.085 \mathrm{mmol})$ in acetone $(20 \mathrm{~mL})$ at room temperature and protected from light, $\left[\mathrm{Ag}\left(\mathrm{OClO}_{3}\right)\left(\mathrm{PPh}_{3}\right)\right](0.040 \mathrm{~g}, 0.085 \mathrm{mmol})$ was added. After 30 minutes of stirring, the orange-brown solid formed was filtered, washed with $\mathrm{n}$-hexane $(5 \mathrm{~mL})$ and air dried $(0.061 \mathrm{~g}$, 87\%).

Anal. Found: $\mathrm{C}, 52.55 ; \mathrm{H}, 3.14 ; \mathrm{N}$, 3.03. Calcd. for $\mathrm{C}_{72} \mathrm{H}_{50} \mathrm{Ag}_{2} \mathrm{~N}_{4} \mathrm{P}_{2} \mathrm{Pt}_{2} \mathrm{C}, 52.76 ; \mathrm{H}, 3.07 ; \mathrm{N}, 3.42$. IR $\left(\mathrm{U}_{\text {max }} / \mathrm{cm}^{-1}\right): 2117$ $(m, C \equiv N), 1596(m, N C), 1575(w, N C), 1560(w, N C), 1542(w$, $\mathrm{NC}), 516\left(\mathrm{~m}, \mathrm{PPh}_{3}\right), 502\left(\mathrm{~m}, \mathrm{PPh}_{3}\right) .{ }^{1} \mathrm{H} \mathrm{NMR}(400.132 \mathrm{MHz}$, $\left.\mathrm{CD}_{2} \mathrm{Cl}_{2}, 298 \mathrm{~K}\right): \delta=8.23\left(2 \mathrm{H}, \mathrm{dd},{ }^{3} J_{\mathrm{H} 2-\mathrm{H} 3}=7.5 \mathrm{~Hz},{ }^{4} J_{\mathrm{H} 2-\mathrm{H} 4}=1.2 \mathrm{~Hz}\right.$, $\left.{ }^{3} J_{\mathrm{H} 2-\mathrm{Pt}}=32.9 \mathrm{~Hz}, \mathrm{H} 2\right), 7.34\left(7 \mathrm{H}, \mathrm{m}, \mathrm{H} 3, \mathrm{H} 4\right.$ and $\left.\mathrm{PPh}_{3}\right), 7.18(15 \mathrm{H}$, $\mathrm{m}, \mathrm{H} 5, \mathrm{H} 7$ and $\left.\mathrm{PPh}_{3}\right), 6.85\left(2 \mathrm{H}, \mathrm{d},{ }^{3} J_{\mathrm{H} 6-\mathrm{H} 7}=8.0 \mathrm{~Hz}, \mathrm{H} 6\right) .{ }^{13} \mathrm{C}\left\{{ }^{1} \mathrm{H}\right\}$ NMR (100.624 MHz, CD $\mathrm{Cl}_{2}, 298 \mathrm{~K}$ ): 167.2 (s, C8), 162.8 (s, C1), 151.8 (s, C9), 140.0 (s, C2), 139.8 (s, C7), 134.1 (d, ${ }^{2} J_{\mathrm{C}-\mathrm{P}}=16.8$ $\left.\mathrm{Hz}, \mathrm{C}-\mathrm{PPh}_{3}\right), 132.1$ (s, C-PPh $)_{3}, 131.8$ (s, CN), 131.5 (s, C-PPh $)_{3}$, 130.5 (s, C3), 129.1 (d, $\left.{ }^{3} J_{C-P}=10.0 \mathrm{~Hz}, \mathrm{C}-\mathrm{PPh}_{3}\right), 125.1$ (s, C4), 124.6 (s, C5), 115.1 (s, C6). ${ }^{31} \mathrm{P}$ NMR (161.992 MHz, $\mathrm{CD}_{2} \mathrm{Cl}_{2}, 193$ $\mathrm{K}): \delta=4.26\left(\mathrm{dd},{ }^{1} \mathrm{~J}_{\mathrm{P}-\mathrm{Ag}}=638.7 \mathrm{~Hz},{ }^{1} J_{\mathrm{P}-\mathrm{Ag}}=552.0 \mathrm{~Hz},{ }^{2} \mathrm{~J}_{\mathrm{P}(\mathrm{Ag}) \mathrm{Pt}}=\right.$ $100.5 \mathrm{~Hz}) .{ }^{195} \mathrm{Pt}\left\{{ }^{1} \mathrm{H}\right\}$ NMR $\left(64.324 \mathrm{MHz}, \mathrm{CD}_{2} \mathrm{Cl}_{2}\right): \delta=-3971(\mathrm{~s}$, $298 \mathrm{~K}$ ), -4012 (ddd, ${ }^{1} \mathrm{JPt}_{\mathrm{Pt} \mathrm{g}}=212.9 \mathrm{~Hz},{ }^{2} \mathrm{JPt}_{\mathrm{P}(\mathrm{Ag})}=108.6 \mathrm{~Hz}, 193 \mathrm{~K}$ ). Mass spectra MALDI+ DIT: $\mathrm{m} / \mathrm{z}=558[\{\mathrm{Pt}(\mathrm{CNC})(\mathrm{CN})\} A g], 369$ $\left[\mathrm{Ag}\left(\mathrm{PPh}_{3}\right)\right]^{+}$.

\section{Preparation of [PtTI(CNC)Cl] (7).}

To a solution of $\left(\mathrm{NBu}_{4}\right)[\mathrm{Pt}(\mathrm{CNC}) \mathrm{Cl}](0.050 \mathrm{~g}, 0.072 \mathrm{mmol})$ in acetone $(20 \mathrm{~mL})$ at room temperature, $\operatorname{TIPF}_{6}(0.025 \mathrm{~g}, 0.072$ $\mathrm{mmol})$ was added. After 45 minutes of stirring, the orange solid formed was filtered, washed with $\mathrm{n}$-hexane $(5 \mathrm{~mL})$ and air dried $(0.022 \mathrm{~g}, 46 \%)$.

IR $\left(U_{\max } / \mathrm{cm}^{-1}\right): 1595(\mathrm{~m}, \mathrm{NC}), 1571(\mathrm{w}, \mathrm{NC}), 1557(\mathrm{w}, \mathrm{NC}), 1538$ (w, NC), $319(\mathrm{~m}, \mathrm{Pt}-\mathrm{Cl})$.

\section{Preparation of $[\mathrm{PtTI}(\mathrm{CNC})(\mathrm{CN})](8)$.}

To a solution of $\left(\mathrm{NBu}_{4}\right)[\mathrm{Pt}(\mathrm{CNC})(\mathrm{CN})](0.050 \mathrm{~g}, 0.072 \mathrm{mmol})$ in acetone $(20 \mathrm{~mL})$ at room temperature, $\operatorname{TIPF}_{6}(0.025 \mathrm{~g}, 0.071$ $\mathrm{mmol}$ ) was added. After 30 minutes of stirring, the yellow solid formed was filtered, washed with $n$-hexane $(5 \mathrm{~mL})$ and air dried (0.026 g, 54\%).

Anal. Found: $\mathrm{C}, 33.01 ; \mathrm{H}, 1.41 ; \mathrm{N}, 4.21$. Calcd for $\mathrm{C}_{18} \mathrm{H}_{11} \mathrm{~N}_{2} \mathrm{PtTl}$ : C, 33.02; H, 1.69; N, 4.28. IR $\left(\mathrm{U}_{\max } / \mathrm{cm}^{-1}\right): 2075(\mathrm{~s}, \mathrm{C} \equiv \mathrm{N}), 1595$ $(\mathrm{m}, \mathrm{NC}), 1575(\mathrm{w}, \mathrm{NC}), 1559(\mathrm{w}, \mathrm{NC}), 1542(\mathrm{w}, \mathrm{NC})$.

\section{Preparation of $\left(\mathrm{NBu}_{4}\right)\left[\{\mathrm{Pt}(\mathrm{CNC})(\mathrm{S}-2 \mathrm{py})\}_{2} \mathrm{Tl}\right](9)$.}

To a solution of $\left(\mathrm{NBu}_{4}\right)[\mathrm{Pt}(\mathrm{CNC})(\mathrm{S}-2 \mathrm{py})](0.100 \mathrm{~g}, 0.120 \mathrm{mmol})$ in acetone $(25 \mathrm{~mL})$ at room temperature, $\mathrm{TIPF}_{6}(0.024 \mathrm{~g}, 0.060$ $\mathrm{mmol}$ ) was added. After 35 minutes of stirring, the reaction mixture was evaporated to dryness. The brown solid formed was extracted with iPrOH $(10 \mathrm{~mL})$, filtered, washed with $\mathrm{n}$ hexane $(5 \mathrm{~mL})$ and air dried $(0.081 \mathrm{~g}, 83 \%)$.

Anal. Found: $\mathrm{C}, 47.25 ; \mathrm{H}, 5.04 ; \mathrm{N}, 4.69 ; \mathrm{S}, 4.18$. Calcd for $\mathrm{C}_{60} \mathrm{H}_{66} \mathrm{~N}_{5} \mathrm{Pt}_{2} \mathrm{~S}_{2} \mathrm{Tl}: \mathrm{C}, 47.54 ; \mathrm{H}, 4.39 ; \mathrm{N}, 4.62 ; \mathrm{S}, 4.23$.

IR $\left(u_{\max } / \mathrm{cm}^{-1}\right): 1593(w, N C), 1575(\mathrm{~m}, \mathrm{NC}), 1557(\mathrm{w}, \mathrm{NC}), 1538$

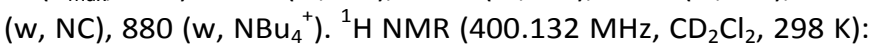
$\delta=7.93\left(2 \mathrm{H}, \mathrm{dd},{ }^{3} J_{\mathrm{H} 2 \mathrm{~S}-2 \mathrm{py}-\mathrm{H} 3 \mathrm{~s}-2 \mathrm{py}}=6.0 \mathrm{~Hz},{ }^{4} J_{\mathrm{H} 2 \mathrm{~S}-2 \mathrm{py}-\mathrm{H} 4 \mathrm{~S}-2 \mathrm{py}}=2.0 \mathrm{~Hz}\right.$, H2S-2py), $7.70\left(2 \mathrm{H}, \mathrm{d},{ }^{3} J_{\mathrm{H} 5 \mathrm{~s}-2 \mathrm{py}-\mathrm{H} 4 \mathrm{~S}-2 \mathrm{py}}=8.0 \mathrm{~Hz}, \mathrm{H} 5 \mathrm{~S}-2 \mathrm{py}\right), 7.63$ $\left(2 \mathrm{H}, \mathrm{t},{ }^{3} \mathrm{~J}_{\mathrm{H} 7 \mathrm{H} 6}=8.0 \mathrm{~Hz}, \mathrm{H} 7\right), 7.47(4 \mathrm{H}, \mathrm{m}, \mathrm{H} 4), 7.35(8 \mathrm{H}, \mathrm{m}, \mathrm{H} 2$ and H6), $7.24\left(2 \mathrm{H}, \mathrm{td},{ }^{3} \mathrm{~J}_{\mathrm{H} 4 \mathrm{~s}-2 \mathrm{py}-\mathrm{H} 5 \mathrm{~s}-2 \mathrm{py}}={ }^{3} \mathrm{~J}_{\mathrm{H} 4 \mathrm{~s}-2 \mathrm{py}-\mathrm{H} 3 \mathrm{~s}-2 \mathrm{py}}=8.0 \mathrm{~Hz}\right.$, $\left.{ }^{4} J_{\mathrm{H} 4 \mathrm{~S}-2 \mathrm{py}-\mathrm{H} 2 \mathrm{~S}-2 \mathrm{py}}=2.0 \mathrm{~Hz}, \mathrm{H} 4 \mathrm{~S}-2 \mathrm{py}\right), 7.02(8 \mathrm{H}, \mathrm{m}, \mathrm{H} 3$ and H5), 6.80 $\left(2 \mathrm{H}, \mathrm{t},{ }^{3} \mathrm{~J}_{\mathrm{H} 3 \mathrm{~S}-2 \mathrm{py}-\mathrm{H} 2 \mathrm{~S}-2 \mathrm{py}}={ }^{3} \mathrm{~J}_{\mathrm{H} 3 \mathrm{~S}-2 \mathrm{py}-\mathrm{H} 4 \mathrm{~S}-2 \mathrm{py}}=6.0 \mathrm{~Hz}, \mathrm{H} 3 \mathrm{~S}-2 \mathrm{py}\right), 3.03$ $\left(2 \mathrm{H}, \mathrm{t},{ }^{3} J_{\mathrm{H} \alpha-\mathrm{H} \beta}=7.3 \mathrm{~Hz}, \mathrm{H \alpha}\left(\mathrm{CH}_{2}-\mathrm{NBu}_{4}{ }^{+}\right)\right), 1.43\left(2 \mathrm{H}, \mathrm{m}, \mathrm{H} \beta\left(\mathrm{CH}_{2}^{-}\right.\right.$ $\left.\left.\mathrm{NBu}_{4}{ }^{+}\right)\right), 1.25\left(2 \mathrm{H}\right.$, sext, ${ }^{3} J_{\mathrm{HY}-\mathrm{H} \beta}={ }^{3} J_{\mathrm{HY}-\mathrm{H} \delta}=7.3 \mathrm{~Hz}, \mathrm{H \gamma}\left(\mathrm{CH}_{2}{ }^{-}\right.$ $\left.\left.\mathrm{NBu}_{4}{ }^{+}\right)\right), 0.89\left(3 \mathrm{H}, \mathrm{t},{ }^{3} \mathrm{~J}_{\mathrm{H} \delta-\mathrm{Hr}}=7.3 \mathrm{~Hz}, \mathrm{H} \delta\left(\mathrm{CH}_{3}-\mathrm{NBu}_{4}{ }^{+}\right)\right)$.

\section{Preparation of [PtTI(CNC)(S-2py)] (10).}

To a solution of $\mathrm{Tl}(\mathrm{acac})(0.050 \mathrm{~g}, 0.016 \mathrm{mmol})$ in $\mathrm{CH}_{2} \mathrm{Cl}_{2}(20$ $\mathrm{mL}$ ) at room temperature, pyridine-2-thiol (0.018 g, 0.016 $\mathrm{mmol})$ was added. After 35 minutes of stirring, $[\mathrm{Pt}(\mathrm{CNC})(\mathrm{dmso})](0.083 \mathrm{~g}, 0.016 \mathrm{mmol})$ was added to the reaction mixture. The resulting solution was stirred during 10 minutes, concentred to $2-3 \mathrm{~mL}$ and $\mathrm{n}$-hexane $(10 \mathrm{~mL})$ was added. The brown solid formed was filtered and air dried (0.070 g, 57\%).

Anal. Found: $\mathrm{C}, 35.23 ; \mathrm{H}, 2.37 ; \mathrm{N}, 3.61 ; \mathrm{S}, 4.85$. Calcd for $\mathrm{C}_{22} \mathrm{H}_{15} \mathrm{~N}_{2}$ PtSTI: C, 35.76; $\mathrm{H}, 2.05 ; \mathrm{N}, 3.79 ; \mathrm{S}, 4.34$.

IR $\left(U_{\max } / \mathrm{cm}^{-1}\right): 1594(w, N C), 1575(\mathrm{~m}, \mathrm{NC}), 1558(\mathrm{w}, \mathrm{NC}), 1540$ (w, NC). ${ }^{1} \mathrm{H}$ NMR (400.132 MHz, $\left.\mathrm{CD}_{2} \mathrm{Cl}_{2}, 298 \mathrm{~K}\right): \delta=8.13(1 \mathrm{H}, \mathrm{d}$, $\left.{ }^{3} J_{\mathrm{H} 2 \mathrm{~S}-2 \mathrm{py}-\mathrm{H} 3 \mathrm{~s}-2 \mathrm{py}}=6.0 \mathrm{~Hz}, \mathrm{H} 2 \mathrm{~S}-2 \mathrm{py}\right), 7.83\left(1 \mathrm{H}, \mathrm{d},{ }^{3} J_{\mathrm{H} 5 \mathrm{~s}-2 \mathrm{py}-\mathrm{H} 4 \mathrm{~S}-2 \mathrm{py}}=\right.$ $8.2 \mathrm{~Hz}, \mathrm{H} 5 \mathrm{~S}-2 \mathrm{py}), 7.71\left(1 \mathrm{H}, \mathrm{t},{ }^{3} \mathrm{~J}_{\mathrm{H} 7-\mathrm{H} 6}=8.0 \mathrm{~Hz}, \mathrm{H} 7\right), 7.55(2 \mathrm{H}, \mathrm{m}$, 
$\mathrm{H} 4), 7.46(3 \mathrm{H}, \mathrm{m}, \mathrm{H} 4 \mathrm{~S}-2 \mathrm{py}$ and $\mathrm{H} 6), 7.32(2 \mathrm{H}, \mathrm{m}, \mathrm{H} 2), 7.10(5 \mathrm{H}$, m, H3S-2py, H3 and H5).

Mass spectra MALDI+ DIT: $m / z=739[[\{\mathrm{Pt}(\mathrm{CNC})(\mathrm{S}-2 \mathrm{py})\} \mathrm{TI}]+\mathrm{H}]^{+}$, $535[\{\mathrm{Pt}(\mathrm{CNC})(\mathrm{S}-2 \mathrm{py})\}+\mathrm{H}]^{+}$.

\section{X-ray structure determinations.}

Crystal data and other details of the structure analyses are presented in Tables S9 and S10 (Supporting Information). Suitable crystals for X-ray diffraction studies were obtained by slow diffusion of $n$-hexane into a concentrated solution of the complex in $3 \mathrm{~mL}$ of $\mathrm{CH}_{2} \mathrm{Cl}_{2}(\mathbf{1}, \mathbf{5}, \mathbf{6}, \mathbf{9}, \mathbf{1 0})$, dimethyformamide $(4,8)$ or $\mathrm{Me}_{2} \mathrm{CO}$. (7). Crystals were mounted at the end of quartz fibres. The radiation used in all cases was graphite monochromated Mo $K_{\alpha}(\lambda=0.71073 \AA ̊ \AA)$. X-ray intensity data were collected on an Oxford Diffraction Xcalibur diffractometer. The diffraction frames were integrated and corrected from absorption by using the CrysAlis RED program. ${ }^{76}$ The structures were solved by Patterson and Fourier methods and refined by full-matrix least squares on $F^{2}$ with different versions of the SHELXL program ${ }^{77}$ (see cif in the Supporting Information). All non-hydrogen atoms were assigned anisotropic displacement parameters and refined without positional constraints, except as noted below. All hydrogen atoms were constrained to idealized geometries and assigned isotropic displacement parameters equal to 1.2 times the $U_{\text {iso }}$ values of their attached parent atoms ( 1.5 times for the methyl hydrogen atoms). For 4, $\mathbf{7}$ and $\mathbf{1 0}$ only small crystals of mediocre quality could be obtained. For the structure of 4, one of the "Pt(CNC)CN" fragments is disordered over two orientations which were refined with partial occupancy 0.531/0.469. Also, three dimethyformamide molecules, used as crystallization solvent, were present and disordered. Restrains on some geometrical and thermal parameters of some of the disordered atoms were used. For the structure of $\mathbf{7}$, an acetone solvent molecule and a water molecule share the same site and they were refined with partial occupancy 0.15 (water)/0.70 (acetone). No hydrogens were added for this low occupancy water molecule and the oxygen was refined isotropically. Full-matrix least-squares refinement of these models against $F^{2}$ converged to final residual indices given in Tables S9 and S10 (Supporting Information). CCDC 1858213-1858220 contain the supplementary crystallographic data for this paper. These data can be obtained free of charge via www.ccdc.cam.ac.uk/data_request/cif, or by emailing data_request@ccdc.cam.ac.uk, or by contacting The Cambridge Crystallographic Data Centre, 12 Union Road, Cambridge CB2 1EZ, UK; fax: +44 1223336033

\section{Conflicts of interest}

There are no conflicts to declare.

\section{Acknowledgements}

This work was supported by the Spanish MINECO/FEDER (Project No. CTQ2015-67461-P) and the Departamento de Industria e Innovación del Gobierno de Aragón and Fondo Social Europeo (Grupo de referencia E17_17R: Química Inorgánica y de los Compuestos Organometálicos).

\section{References}

1. S. Sculfort and P. Braunstein, Chem. Soc. Rev., 2011, 40, 2741-2760.

2. M.-E. Moret, Top. Organomet. Chem., 2011, 35, 157-184.

3. J. Bauer, H. Braunschweig and R. D. Dewhurst, Chem. Rev., 2012, 112, 4329-4346.

4. H. Schmidbaur and A. Schier, Chem. Soc. Rev., 2012, 41, 370-412.

5. M. J. Katz, K. Sakai and D. B. Leznoff, Chem. Soc. Rev., 2008, 37, 1884-1895.

6. J. R. Berenguer, E. Lalinde and M. T. Moreno, Coord. Chem. Rev., 2018, 366, 69-90.

7. V. W.-W. Yam, V. K.-M. Au and S. Y.-L. Leung, Chem. Rev., 2015, 115, 7589-7728.

8. A. Díez, E. Lalinde and M. T. Moreno, Coord. Chem. Rev., 2011, 255, 2426-2447.

9. D. R. Pye and N. P. Mankad, Chem. Sci., 2017, 8, 17051718.

10. M.-E. Moret, D. Serra, A. Bach and P. Chen, Angew. Chem. Int. Ed., 2010, 49, 2873-2877.

11. D. Serra, M.-E. Moret and P. Chen, J. Am. Chem. Soc., 2011, 133, 8914-8926.

12. G. J. Arsenault, C. M. Anderson and R. J. Puddephatt, Organometallics, 1988, 7, 2094-2097.

13. M. H. Pérez-Temprano, J. A. Casares, Á. R. de Lera, R. Álvarez and P. Espinet, Angew. Chem. Int. Ed., 2012, 51, 4917-4920.

14. M. M. Hansmann, M. Pernpointner, R. Döpp and A. S. K. Hashmi, Chem, Eur. J., 2013, 19, 15290-15303.

15. D. Carrasco, M. H. Pérez-Temprano, J. A. Casares and P. Espinet, Organometallics, 2014, 33, 3540-3545.

16. R. J. Oeschger, D. H. Ringger and P. Chen, Organometallics, 2015, 34, 3888-3892.

17. B. Fuentes, M. García-Melchor, A. Lledós, F. Maseras, J. A. Casares, G. Ujaque and P. Espinet, Chem. Eur. J., 2010, 16, 8596-8599.

18. R. J. Oeschger and P. Chen, J. Am. Chem. Soc., 2017, 139, 1069-1072.

19. R. J. Oeschger and P. Chen, Organometallics, 2017, 36, 1465-1468.

20. M. Baya, Ú. Belío, I. Fernández, S. Fuertes and A. Martín, Angew. Chem. Int. Ed., 2016, 55, 6978-6982.

21. M. Baya, Ú. Belío, J. Forniés, A. Martín, M. Perálvarez and V. Sicilia, Inorg. Chim. Acta, 2015, 424, 136-149.

22. A. Martín, U. Belío, S. Fuertes and V. Sicilia, Eur. J. Inorg. Chem., 2013, 2231-2247.

23. J. Forniés, S. Ibáñez, E. Lalinde, A. Martín, M. T. Moreno and A. C. Tsipis, Dalton Trans., 2012, 41, 3439-3451.

24. M. Baya, U. Belio, D. Campillo, I. Fernandez, S. Fuertes and A. Martin, Chem. Eur. J., 2018, 24, 13879-13889.

25. M.-E. Moret and P. Chen, J. Am. Chem. Soc., 2009, 131, 5675-5690.

26. J. R. Berenguer, E. Lalinde, A. Martín, M. T. Moreno, S. Sánchez and H. R. Shahsavari, Inorg. Chem., 2016, 55, 7866-7878. 
27. J. Forniés, N. Giménez, S. Ibáñez, E. Lalinde, A. Martín and M. T. Moreno, Inorg. Chem., 2015, 54, 4351-4363.

28. Ú. Belío, S. Fuertes and A. Martín, Dalton Trans., 2014, 43 10828-10843.

29. S. Fuertes, A. J. Chueca, A. Martín and V. Sicilia, Cryst. Growth Des., 2017, 17, 4336-4346.

30. T. Yamaguchi, F. Yamazaki and T. Ito, J. Am. Chem. Soc., 1999, 121, 7405-7406.

31. J. Fornies, S. Ibanez, A. Martin, B. Gil, E. Lalinde and M. T. Moreno, Organometallics, 2004, 23, 3963-3975.

32. J. R. Berenguer, E. Lalinde, A. Martín, M. T. Moreno, S. Ruiz, S. Sánchez and H. R. Shahsavari, Inorg. Chem., 2014, 53, 8770-8785.

33. A. L. Liberman-Martin, D. S. Levine, M. S. Ziegler, R. G. Bergman and T. D. Tilley, Chem. Commun., 2016, 52, 70397042.

34. Ú. Belío, S. Fuertes and A. Martín, Inorg. Chem., 2013, 52, 5627-5629.

35. J. R. Berenguer, E. Lalinde and J. Torroba, Inorg. Chem., 2007, 46, 9919-9930.

36. C. K.-L. Li, R. W.-Y. Sun, S. C.-F. Kui, N. Zhu and C.-M. Che, Chem. Eur. J., 2006, 12, 5253-5266.

37. J. Moussa, K. Haddouche, L.-M. Chamoreau, H. Amouri and J. A. Gareth Williams, Dalton Trans., 2016, 45, 1264412648.

38. H. Sesolis, C. K.-M. Chan, G. Gontard, H. L.-K. Fu, V. W.-W. Yam and H. Amouri, Organometallics, 2017, 36, 4794-4801.

39. S. Fuertes, C. H. Woodall, P. R. Raithby and V. Sicilia, Organometallics, 2012, 31, 4228-4240.

40. L. Schneider, V. Sivchik, K.-y. Chung, Y.-T. Chen, A. J. Karttunen, P.-T. Chou and I. O. Koshevoy, Inorg. Chem., 2017, 56, 4459-4467.

41. Several of these complexes are known differing in their structural arrangement in the solid state: one dimensional infinite chains (M. Hong, W. Su, R. Cao, W. Zhang and J. Lu, Inorg. Chem. 1999, 38, 600-602), two dimensional layers (W. Su, M. Hong, J. Weng, Y. Liang, Y. Zhao, R. Cao, Z. Zhou and A. S. C. Chan, Inorg. Chim. Acta 2002, 331, 8-15), or discrete $[\mathrm{Ag}(\mathrm{S}-2 \mathrm{py})]$ (L. Han, Z. Chen, J. Luo, M. Hong and R. Cao, Acta Cryst. Sect. E, 2002, 58, 383-384).

42. H. Schmidbaur and A. Schier, Angew. Chem. Int. Ed., 2015, 54, 746-784.

43. K. Nakamoto, Infrared and Raman Spectra of Inorganic and Coordination Compunds. Part B, Sixth edn., John Wiley \& Sons, Hoboken, New Jersey, 2009.

44. J. Forniés, S. Ibáñez, A. Martín, M. Sanz, J. R. Berenguer, E. Lalinde and J. Torroba, Organometallics, 2006, 25, 43314340.

45. L. R. Falvello, J. Forniés, R. Garde, A. García, E. Lalinde, M. T. Moreno, A. Steiner, M. Tomás and I. Usón, Inorg. Chem., 2006, 45, 2543-2552.

46. Á. Díez, J. Fernández, E. Lalinde, M. T. Moreno and S. Sánchez, Inorg. Chem., 2010, 49, 11606-11618.

47. J. Forniés, A. García, E. Lalinde and M. T. Moreno, Inorg. Chem., 2008, 47, 3651-3660.

48. J. Forniés, S. Fuertes, A. Martín, V. Sicilia, B. Gil and E. Lalinde, Dalton Trans., 2009, 2224-2234.

49. V. Sicilia, J. Forniés, S. Fuertes and A. Martín, Inorg. Chem., 2012, 51, 10581-10589.

50. E. J. Fernández, A. Laguna, J. M. López de Luzuriaga, M. E. Olmos and J. Pérez, Dalton Trans., 2004, 1801-1806.
51. R. Usón, J. Forniés, B. Menjón, F. A. Cotton, L. R. Falvello and M. Tomás, Inorg. Chem., 1985, 24, 4651-4656.

52. S. Jamali, Z. Mazloomi, S. M. Nabavizadeh, D. Milic, R. Kia and M. Rashidi, Inorg. Chem., 2010, 49, 2721-2726.

53. J. Forniés, F. Martínez, R. Navarro and E. P. Urriolabeitia, Organometallics, 1996, 15, 1813-1819.

54. J. Moussa, L. M. Chamoreau, M. P. Gullo, A. Degli Esposti, A. Barbieri and H. Amouri, Dalton Trans., 2016, 45, 29062913.

55. M. H. Pérez-Temprano, J. A. Casares and P. Espinet, Chem, Eur. J., 2012, 18, 1864-1994.

56. R. Usón, J. Forniés, M. Tomás, R. Garde and R. Merino, Inorg. Chem., 1997, 36, 1383-1387.

57. A. L. Balch and S. P. Rowley, J. Am. Chem. Soc., 1990, 112, 6139-6140.

58. N. Oberbeckmann-Winter, P. Braunstein and R. Welter, Organometallics, 2004, 23, 6311-6318.

59. J. Forniés, C. Fortuño, S. Ibáñez and A. Martín, Inorg. Chem., 2008, 47, 5978-5987.

60. J. K. Nagle, A. L. Balch and M. M. Olmstead, J. Am. Chem. Soc., 1988, 110, 319-321.

61. J. P. H. Charmant, J. Forniés, J. Gómez, E. Lalinde, R. I. Merino, M. T. Moreno and A. G. Orpen, Organometallics, 2003, 22, 652-656.

62. F. Liu, W. Chen and D. Wang, Chin. J. Struct. Chem., 2006, 25, 677-680.

63. J. R. Berenguer, J. Fernández, E. Lalinde and S. Sánchez, Chem. Commun, 2012, 48, 6384-6386.

64. H. B. Song, Z.-Z. Zhang, Z. Hui, C.-M. Che and T. C. W. Mak, Inorg. Chem., 2002, 41, 3146-3154.

65. O. Renn, B. Lippert and I. Mutikainen, Inorg. Chim. Acta, 1993, 208, 219-223.

66. W. Chen, F. Liu, D. X. Xu, K. Matsumoto, S. Kishi and M. Kato, Inorg. Chem., 2006, 45, 5552-5560.

67. S. Jamali, N.-a. Mousavi, M. Bagherzadeh, R. Kia and H. Samouei, Dalton Trans., 2017, 46, 11327-11334.

68. J. R. Stork, M. M. Olmstead, J. C. Fettinger and A. L. Balch, Inorg. Chem., 2006, 45, 849-857.

69. J. R. Stork, M. M. Olmstead and A. L. Balch, J. Am. Chem. Soc., 2005, 127, 6512-6513.

70. A. Díez, J. Forniés, J. Gómez, E. Lalinde, A. Martín, M. T. Moreno and S. Sánchez, Dalton Trans., 2007, 3653-3660.

71. A. Díez, J. Fernández, E. Lalinde, M. T. Moreno and S. Sánchez, Inorg. Chem., 2010, 49, 11606-11618.

72. J. R. Berenguer, J. Forniés, B. Gil and E. Lalinde, Chem. Eur. J., 2006, 12, 785-795.

73. G. Wu and D. Wang, J. Cluster Sci., 2007, 18, 406-413.

74. J. Forniés, V. Sicilia, J. M. Casas, A. Martín, J. A. López, C. Larraz, P. Borja and C. Ovejero, Dalton Trans., 2011, 40, 2898-2912.

75. T. Yamaguchi, F. Yamazaki and T. Ito, J. Am. Chem. Soc., 2001, 123, 743-744.

76. CrysAlis RED, CCD camera data reduction program, Oxford Diffraction, Oxford, UK, 2004.

77. G. M. Sheldrick, Acta Cryst., 2008, A64, 112-122. 